Article

\title{
Synthesis of New Triazolopyrazine Antimalarial Compounds
}

\author{
Daniel J. G. Johnson ${ }^{1}$, Ian D. Jenkins ${ }^{1}$, Cohan Huxley ${ }^{1}$, Mark J. Coster ${ }^{1}$, Kah Yean Lum ${ }^{1,2}$, Jonathan M. White ${ }^{3}$, \\ Vicky M. Avery ${ }^{1,4}$ and Rohan A. Davis $1,2, * \mathbb{D}$ \\ 1 Griffith Institute for Drug Discovery, School of Environment and Science, Griffith University, \\ Brisbane, QLD 4111, Australia; d.johnson@griffithuni.edu.au (D.J.G.J.); i.jenkins@griffith.edu.au (I.D.J.); \\ c.huxley@griffithuni.edu.au (C.H.); m.coster@griffith.edu.au (M.J.C.); k.lum@griffith.edu.au (K.Y.L.); \\ v.avery@griffith.edu.au (V.M.A.) \\ 2 NatureBank, Griffith University, Brisbane, QLD 4111, Australia \\ 3 School of Chemistry and Bio21 Institute, The University of Melbourne, Melbourne, VIC 3010, Australia; \\ whitejm@unimelb.edu.au \\ 4 Discovery Biology, Griffith University, Brisbane, QLD 4111, Australia \\ * Correspondence: r.davis@griffith.edu.au; Tel.: +61-7-3735-6043
}

Citation: Johnson, D.J.G.; Jenkins, I.D.; Huxley, C.; Coster, M.J.; Lum,

K.Y.; White, J.M.; Avery, V.M.; Davis,

R.A. Synthesis of New

Triazolopyrazine Antimalarial

Compounds. Molecules 2021, 26, 2421.

https://doi.org/10.3390/

molecules26092421

Academic Editor: Michael John Plater

Received: 31 March 2021

Accepted: 15 April 2021

Published: 21 April 2021

Publisher's Note: MDPI stays neutral with regard to jurisdictional claims in published maps and institutional affiliations.

Copyright: (C) 2021 by the authors. Licensee MDPI, Basel, Switzerland. This article is an open access article distributed under the terms and conditions of the Creative Commons Attribution (CC BY) license (https:/ / creativecommons.org/licenses/by/ $4.0 /)$.

\begin{abstract}
A radical approach to late-stage functionalization using photoredox and Diversinate ${ }^{\mathrm{TM}}$ chemistry on the Open Source Malaria (OSM) triazolopyrazine scaffold (Series 4) resulted in the synthesis of 12 new analogues, which were characterized by NMR, UV, and MS data analysis. The structures of four triazolopyrazines were confirmed by X-ray crystal structure analysis. Several minor and unexpected side products were generated during these studies, including two resulting from a possible disproportionation reaction. All compounds were tested for their ability to inhibit the growth of the malaria parasite Plasmodium falciparum (3D7 and Dd2 strains) and for cytotoxicity against a human embryonic kidney (HEK293) cell line. Moderate antimalarial activity was observed for some of the compounds, with $\mathrm{IC}_{50}$ values ranging from 0.3 to $>20 \mu \mathrm{M}$; none of the compounds displayed any toxicity against HEK293 at $80 \mu \mathrm{M}$.
\end{abstract}

Keywords: Open Source Malaria; drug discovery; synthesis; triazolopyrazine; late-stage functionalization; photoredox; Diversinate ${ }^{\mathrm{TM}}$; methylation; difluoroethylation; antimalarial; $\mathrm{X}$-ray; radical disproportionation; mechanism

\section{Introduction}

The 1,2,4-triazolo[4,3-a]pyrazine scaffold has been shown to display a variety of biological activities of importance to drug discovery and development, as well as chemical biology research. Examples of bioactivity associated with this electron-deficient and nitrogen-rich heterocyclic scaffold include compounds that bind to the N-methyl-D-aspartate subtype $2 \mathrm{~B}$ receptor, which plays an important role in neurological disease states [1], patented inhibitors of renal outer medullary potassium channels [2], compounds that inhibit kidney urea transport [3], and bromodomain inhibitors, which may have implications for future cancer therapies [4].

For the past few years, the Open Source Malaria (OSM) consortium [5] has had a growing interest in the 1,2,4-triazolo[4,3-a]pyrazine scaffold, which has been designated Series 4 [6]. This compound series is believed to have several advantages over the previous series that have been or are being investigated within the OSM. In vitro testing has revealed human liver microsomal and hepatocyte stability, as well as hepatic intrinsic clearance of $<8.1 \mu \mathrm{L} / \mathrm{min} / \mathrm{mg}$ [6]. The series has demonstrated potency down to $0.016 \mu \mathrm{M}$ against the malaria parasite Plasmodium falciparum (Pf) and appears to have little poly-pharmacology or cytotoxicity, giving confidence in its specificity and tolerability, making it ideal for a targeted medication [6]. A number of the more potent triazolopyrazine compounds identified to date are shown below in Figure 1, along with in vitro $\mathrm{IC}_{50}$ values. Through OSM investigations into the mechanism of action of the Series 4 compounds, it has been suggested that these 
compounds inhibit the ATPase, PfATP4 [7]. The inhibition of PfATP4 has been investigated with a number of other antimalarial compounds, including compounds based on 4-cyano3-methylisoquinolines [8], and pyrazoloamides [9]. PfATP4 is considered to function as a $\mathrm{Na}^{+} / \mathrm{H}^{+}$-ATPase, which allows the malaria parasite to regulate $\mathrm{Na}^{+}$to maintain cell homeostasis [9-11]. It was proposed that Series 4 compounds have the ability to interfere with this process, which means the parasite is unable to regulate $\mathrm{Na}^{+}$[7]. The disruption of $\mathrm{Na}^{+}$regulation results in a significant increase in the acid load of the cell, which can lead to parasite growth inhibition and ultimately parasite death [9-11].

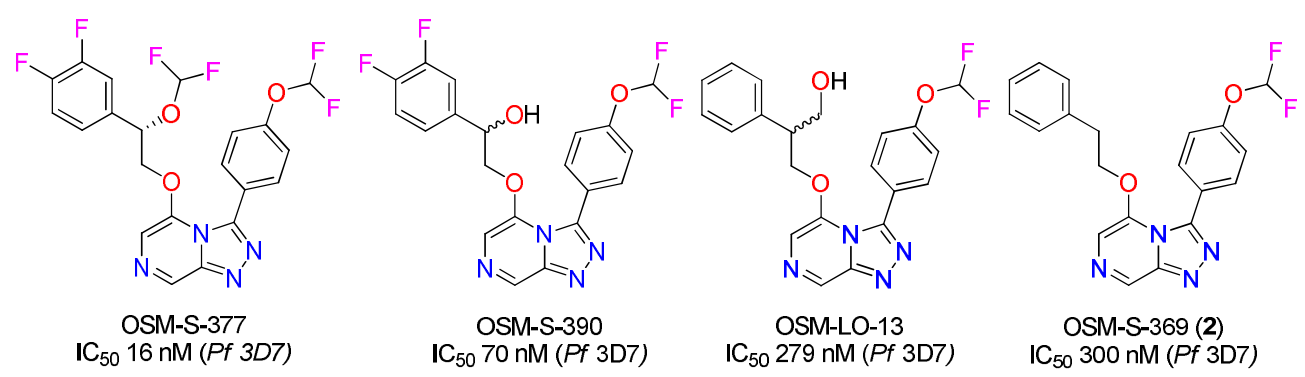

Figure 1. Some analogues under investigation by the OSM, including OSM-S-369, which was further investigated in this work [6].

A current aim for the Series 4 lead optimization involves improving solubility and metabolic stability, while maintaining potency [6]. Late-stage functionalization (LSF), incorporating small incremental modifications, has been employed to achieve this [4]. This strategy involves using $\mathrm{C}-\mathrm{H}$ bonds as chemical handles for functionalization, bypassing the need for de novo synthetic strategies that may be costly and time consuming.

Herein we report the synthesis of several new triazolopyrazine derivatives employing LSF radical chemistry, in particular, photoredox methylations and Diversinate ${ }^{\mathrm{TM}}$ transfor- $^{-}$ mations. In vitro antimalarial activity and cytotoxicity are also reported for all analogues generated during these studies.

\section{Results and Discussion}

2.1. Synthesis of OSM-Based Scaffolds via Coupling of Primary Alcohols with Chloro-Heterocycles

Compound 1, which was used in this project as a scaffold for semisynthesis and late-stage functionalization, has been previously synthesized and reported by the OSM project [12]. Initially, scaffold 1 was converted into a series of ether-substituted triazolopyrazine compounds, using a procedure (Scheme 1) based on that reported by Tse [13].<smiles>FC(F)Oc1ccc(-c2nnc3cncc(Cl)n23)cc1</smiles>

1<smiles>FC(F)Oc1ccc(-c2nnc3cncc(OCCc4ccccc4)n23)cc1</smiles>

$2(20 \%)$

Scheme 1. Synthesis of compound 2.

Two of the ether triazolopyrazine derivatives (compounds 2 and 3) were known OSM compounds. Compound 2, previously reported to display potent activity against $P f$ 3D7 with an $\mathrm{IC}_{50}$ value of $0.301 \mu \mathrm{M}$ [14], was synthesized as the starting point for the proposed photoredox catalysis reactions and LSF Diversinate ${ }^{\mathrm{TM}}$ chemistry. Compound 1 was treated with 2-phenylethanol, potassium hydroxide $(\mathrm{KOH})$, and 18-crown-6, dissolved in toluene $(\mathrm{PhMe})$, and then briefly heated (Scheme 1$)$. The reaction products were subsequently 
purified by silica flash chromatography using $n$-hexane/EtOAc stepwise gradient to afford pure 2. No reaction optimization was undertaken since a sufficient quantity of the triazolopyrazine derivative 2 was obtained for the planned LSF chemistry.

Compound 3, a previously reported OSM compound with low Pf activity $\left(\mathrm{IC}_{50}=10 \mu \mathrm{M}\right)$, was part of the inherited data set reported in the OSM master compounds' list [15]. It was synthesized as an alternative starting point for the proposed photoredox catalysis reactions and LSF Diversinate ${ }^{\mathrm{TM}}$ chemistry. The synthesis of this compound was accompanied by the formation of an unexpected and unusual side product 4 (Scheme 2). The mechanism of formation of $\mathbf{4}$ is presumably analogous to that for the formation of $\mathbf{6}$ (Scheme 3) except that the attacking nucleophile is hydroxide rather than alkoxide. The strong inductive effect exerted by the three 1 -fluorines of the 2,2,2-trifluoroethanol would decrease the nucleophilicity of the corresponding alkoxide, rendering hydroxide a competitive nucleophile.<smiles>FC(F)Oc1ccc(-c2nnc3cncc(Cl)n23)cc1</smiles><smiles>OCC(F)(F)F</smiles><smiles>CC(C)[18OH]</smiles>

$\mathrm{PhMe}, 40^{\circ} \mathrm{C}, 2 \mathrm{~h}$<smiles>FC(F)Oc1ccc(-c2nnc3cncc(OCC(F)(F)F)n23)cc1</smiles>

$3(17 \%)$<smiles>Oc1nccn2c(-c3ccc(OC(F)F)cc3)nnc12</smiles>

$4(6 \%)$

Scheme 2. Synthesis of compound 3 and side product 4 .<smiles>FC(F)Oc1ccc(-c2nnc3cncc(Cl)n23)cc1</smiles>

1<smiles>C[Si](C)(C)CCO</smiles>

$\mathrm{KOH}, 18-$ crown-6

$\mathrm{PhMe}, 40^{\circ} \mathrm{C}, 3 \mathrm{~h}$<smiles></smiles>

$5(24 \%)$<smiles>C[Si](C)(C)CCOc1nccn2c(-c3ccc(OC(F)F)cc3)nnc12</smiles>

$6(7 \%)$

Scheme 3. Synthesis of compounds 5 and 6.

Crystals of compound 3 were successfully analyzed via X-ray crystallography, confirming the structure assignment (Figure 2). This is the first reported crystal structure of an ether-substituted triazolopyrazine.

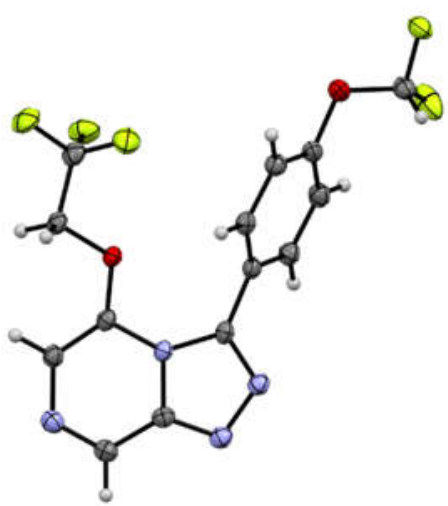

Figure 2. ORTEP drawing of compound 3. 
The novel compound 5 was also synthesized using the commercially available primary alcohol, 2-(trimethylsilyl)ethanol. A triazolopyrazine derivative containing silicon that was chosen as the OSM project had not previously investigated any silyl analogues. While silicon-based drugs are rare, some examples of drug-like candidates containing silicon, which are bioavailable via an oral route of administration, are known [16].

Compound 5 was produced using the previously described method, except that the reaction time was increased to $3 \mathrm{~h}$ (Scheme 3). The synthesis of compound 5 was accompanied by the formation of another unusual side product (6). A proposed mechanism for how the tele-substitution product $\mathbf{6}$ is formed was recently published by Todd et al. [17].

The structures of all synthesized ethers and side products were determined using 1D/2D NMR and HRMS (see Supplementary Materials). An example of the full characterization for the new compound $\mathbf{5}$ is given below. Compound $\mathbf{5}$ was isolated as brown crystals and was assigned the molecular formula $\mathrm{C}_{17} \mathrm{H}_{20} \mathrm{~F}_{2} \mathrm{~N}_{4} \mathrm{O}_{2} \mathrm{Si}$ following analysis of HRESIMS ion at $m / z 379.1396[\mathrm{M}+\mathrm{H}]^{+}$(calcd for $\mathrm{C}_{17} \mathrm{H}_{21} \mathrm{~F}_{2} \mathrm{~N}_{4} \mathrm{O}_{2} \mathrm{Si}$, 379.1396). The ${ }^{1} \mathrm{H}$ NMR spectrum in DMSO- $d_{6}$ for 5 (Table 1 ) indicated the presence of two methylenes [ $\delta_{\mathrm{H}} 0.91$ $(\mathrm{H}-22)$ and $4.33(\mathrm{H}-21)]$ and four aromatic protons $\left[\delta_{\mathrm{H}} 7.81(\mathrm{H}-11\right.$ and $\mathrm{H}-15)$ and $7.31(\mathrm{H}-12$ and $\mathrm{H}-14)]$. The ${ }^{2} J_{\mathrm{HF}}$ splitting of a triplet $(73.6 \mathrm{~Hz})$ was used to identify the proton located in the difluoromethoxy group $\left[\delta_{\mathrm{H}} 7.36(\mathrm{H}-17)\right]$, and a strong singlet signal was used to identify the trimethylsilyl group $\left[\delta_{\mathrm{H}} 0.07(\mathrm{H}-24, \mathrm{H}-25\right.$ and $\mathrm{H}-26)$. The ${ }^{13} \mathrm{C}$ NMR spectrum and edited HSQC spectrum indicated the presence of 17 carbons, including three methyls, two methylenes, six aromatic methines, one fluorinated methine, and five non-protonated $\mathrm{sp}^{2}$ carbons.

Table 1. NMR data for compound 5 in DMSO- $d_{6}$ a.

\begin{tabular}{|c|c|c|c|c|c|}
\hline Position & $\begin{array}{l}\delta_{H}, \text { mult., } J \\
\text { in } \mathrm{Hz} \text {, int. }\end{array}$ & $\begin{array}{c}\delta_{C}, \text { mult., } J \\
\text { in } \mathrm{Hz}\end{array}$ & COSY & НМВС & ROESY \\
\hline 3 & & $145.6, \mathrm{~s}$ & & & \\
\hline 5 & & $143.9, \mathrm{~s}$ & & & \\
\hline 6 & $7.59, \mathrm{~s}, 1 \mathrm{H}$ & 109.1, s & & 5,8 & 21 \\
\hline 8 & $9.01, \mathrm{~s}, 1 \mathrm{H}$ & $134.7, \mathrm{~s}$ & & 6,9 & \\
\hline 9 & & $147.4, \mathrm{~s}$ & & & \\
\hline 10 & & $124.8, \mathrm{~s}$ & & & \\
\hline 11 & $7.81, \mathrm{~m}, 1 \mathrm{H}$ & $132.8, \mathrm{~s}$ & 12 & $3,13,15$ & 12 \\
\hline 12 & $7.31, \mathrm{~m}, 1 \mathrm{H}$ & 117.6, s & 11 & 10,14 & 11 \\
\hline 13 & & $151.9, t, 3.3$ & & & \\
\hline 14 & $7.31, \mathrm{~m}, 1 \mathrm{H}$ & $117.6, \mathrm{~s}$ & 15 & 10,12 & 15 \\
\hline 15 & $7.81, \mathrm{~m}, 1 \mathrm{H}$ & $132.8, \mathrm{~s}$ & 14 & $3,11,13$ & 14 \\
\hline 17 & $7.36, \mathrm{t}, 73.6,1 \mathrm{H}$ & $116.1, \mathrm{t}, 258.5$ & & 13 & \\
\hline 21 & $4.33, \mathrm{~m}, 2 \mathrm{H}$ & $69.4, \mathrm{~s}$ & 22 & 5,22 & 6,22 \\
\hline 22 & $0.91, \mathrm{~m}, 2 \mathrm{H}$ & $16.5, \mathrm{~s}$ & 21 & $21,24,25,26$ & $21,24,25,26$ \\
\hline 24 & $0.07, \mathrm{~s}, 3 \mathrm{H}$ & $-1.7, \mathrm{~s}$ & & $22,25,26$ & 22 \\
\hline 25 & $0.07, \mathrm{~s}, 3 \mathrm{H}$ & $-1.7, \mathrm{~s}$ & & $22,24,26$ & 22 \\
\hline 26 & $0.07, \mathrm{~s}, 3 \mathrm{H}$ & $-1.7, \mathrm{~s}$ & & $22,24,25$ & 22 \\
\hline
\end{tabular}

a Recorded at $500 \mathrm{MHz}\left({ }^{1} \mathrm{H}\right.$ NMR $)$ and $125 \mathrm{MHz}\left({ }^{13} \mathrm{C}\right.$ NMR $)$ at $25^{\circ} \mathrm{C}$.

Analysis of the COSY system was able to corroborate the relationship of the doublet signals in the aromatic ring as being a part of the same spin system (H-11, H-12, H-14, and $\mathrm{H}-15)$. Analysis of the ${ }^{13} \mathrm{C}$ NMR and $\mathrm{HMBC}$ correlations from the difluoromethoxy proton along with ${ }^{3} J_{\mathrm{C}-\mathrm{F}}$ splitting $(3.3 \mathrm{~Hz})$ allowed for the unambiguous assignment of C-13 $\left(\delta_{C} 151.9\right)$. This then allowed for definitive NMR assignments of the rest of the aromatic ring. Of note, $\mathrm{HMBC}$ correlations for $\mathrm{H}-11$ and $\mathrm{H}-15$ were identified to $\delta_{\mathrm{C}} 151.9$. Furthermore, another strong HMBC correlation from both $\mathrm{H}-11$ and $\mathrm{H}-15$ facilitated the assignment of $C-3\left(\delta_{C} 145.6\right)$ on the triazolo ring. The coupling between the methylene protons $\delta_{\mathrm{H}} 4.33(\mathrm{H}-21)$ and $\delta_{\mathrm{H}} 0.91(\mathrm{H}-22)$ observed in COSY spectrum, together with a key ROESY correlation from $\delta_{\mathrm{H}} 4.33$ to $\delta_{\mathrm{H}} 7.59(\mathrm{H}-6)$ and the HBMC correlations from the $\delta_{\mathrm{H}} 4.33$ to $\delta_{\mathrm{C}} 143.9$, supported the addition of the ether sidechain to the triazolopyrazine 
core at $\mathrm{C}-5$. The HMBC correlation between the methylene $\mathrm{H}-22$ to the trimethylsilyl group carbons C-24, C-25, and C-26 $\left(\delta_{C}-1.7\right)$ further confirmed the presence of trimethylsilyl ether. Key COSY, HMBC, and ROESY correlations for compound 5 are shown in Figure 3. These data enabled the chemical structure of 5 to be assigned. Furthermore, crystals obtained for $\mathbf{5}$ following silica flash chromatography and subsequent $X$-ray crystallography studies confirmed the NMR-based structure assignment. The ORTEP drawing of $\mathbf{5}$ is shown below in Figure 4.

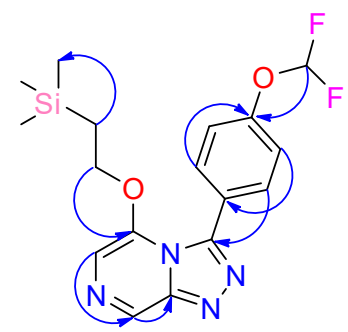<smiles>CC(F)Oc1ccc(-c2nnc3cnc4c(n23)OC(C(F)F)CCC4[Si](C)(C)C)cc1</smiles>

Figure 3. Key HMBC $(\rightarrow)$, ROESY $(\leftrightarrow)$, and COSY $(-)$ correlations for 5.

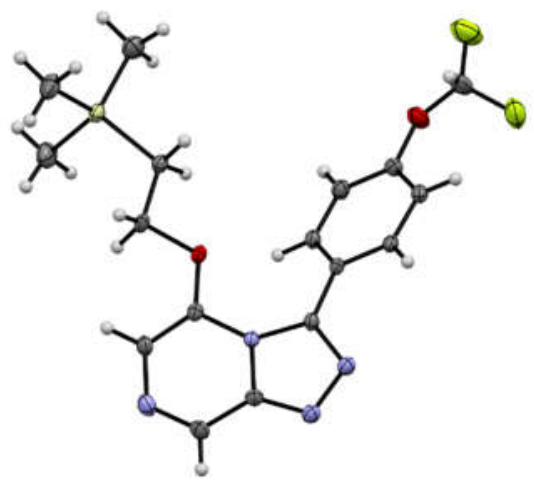

Figure 4. ORTEP drawing of compound 5.

\subsection{Late-Stage Functionalization: Methylation of Series 4 Scaffolds and Ether Derivatives via Photoredox Catalysis}

The first LSF reactions utilizing photoredox catalysis involved the use of a linear reflector made by Kessil ${ }^{\circledR}$, which allowed for control over the intensity of the blue light $(456 \mathrm{~nm})$ and reaction vessel distance from the light source. The scaffolds 1, 7, and 9, were initially used to test the methylation photoredox chemistry, based on methodology reported by DiRocco et al. [18]. Reactions were carried out using the scaffold substrate $(0.1 \mathrm{mmol}), t$-butyl peracetate $\left(3 \mathrm{eq}\right.$.), iridium catalyst $\left.\left[\mathrm{Ir}\left(\mathrm{dF}-\mathrm{CF}_{3}-\mathrm{ppy}\right)_{2}(\mathrm{dtbpy})\right] \mathrm{PF}_{6}\right]$ ( $2 \mathrm{~mol} \%$ ). The nitrogen-sparged 1:1 TFA/ACN reaction mixture was stirred for $16 \mathrm{~h}$ while being irradiated with blue light from the Kessi ${ }^{\circledR}$ photoreactor. Purification of the crude reaction products was carried out using reversed phase $\mathrm{C}_{18} \mathrm{HPLC}\left(\mathrm{MeOH} / \mathrm{H}_{2} \mathrm{O} / 0.1 \%\right.$ TFA). Products and yields are reported in Scheme 4 below. 
<smiles>Clc1ccc(-c2nnc3cncc(Cl)n23)cc1</smiles>

7<smiles>N#Cc1ccc(-c2nnc3cncc(Cl)n23)cc1</smiles>

9

\section{$t$-butyl peracetate ( 3 eq.) \\ 2 mol\% [Ir(df-CF - ppy $)_{2}$ (dtbpy)]PF \\ 1:1 TFA:ACN \\ Blue light, $16 \mathrm{~h}$ \\ $45 \mathrm{~W} / \mathrm{cm}^{2}$}

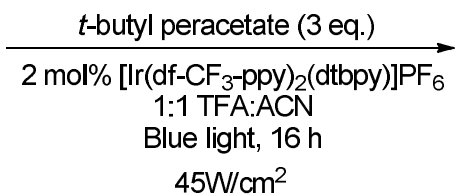

$45 \mathrm{~W} / \mathrm{cm}^{2}$<smiles>FC(F)Oc1ccc(-c2nnc3cncc(Cl)n23)cc1</smiles>

1

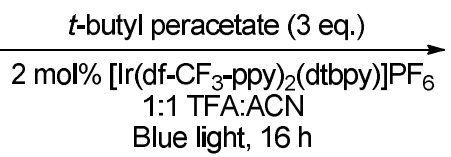<smiles>N#Cc1ccc(-c2nnc3c(Br)ncc(Cl)n23)cc1</smiles><smiles>O=[13C]c1ncc(Cl)n2c(-c3ccc(Cl)cc3)nnc12</smiles><smiles>FC(F)Oc1ccc(-c2nnc3c([Tl])ncc(Cl)n23)cc1</smiles>

Yield @ 45 W/cm²: 11\%

Yield @ 40 W/cm²: 11\%

Yield @ $30 \mathrm{~W} / \mathrm{cm}^{2}:$ 15\%

Yield@ 20 W/cm²: 39\%

Scheme 4. Synthesis of $\mathbf{8}, \mathbf{1 0}$, and 11 via photoredox-catalyzed methylation (for structure of the iridium catalyst, see Ref. [16]).

It was found that the yield of compound $\mathbf{1 1}$ could be significantly improved by reducing the light intensity from 45 to $20 \mathrm{~W} / \mathrm{cm}^{2}$ (Scheme 4). Compounds $\mathbf{8}, \mathbf{1 0}$, and $\mathbf{1 1}$ were fully characterized using 1D/2D NMR and HRMS in order to confirm the methylation site on this heterocyclic scaffold.

Using these optimized reaction conditions described above, scaffold 3 was converted into the methylated derivative $\mathbf{1 2}$ in $23 \%$ yield (Scheme 5). However, using the same reaction conditions with scaffold 5 did not produce any methylated product. As all of the starting material had been consumed (as determined by LCMS), either $\mathbf{5}$ (or methylated $\mathbf{5}$ ) must have been degraded, possibly via photodegradation, a noted criticism of photoredox synthesis in the literature [19]. Taking this into account with the methylation reaction of $\mathbf{2}$, the reaction time was reduced from 16 to $12 \mathrm{~h}$, resulting in the methylated product 13 in $43 \%$ yield (Scheme 5 ). 
<smiles>FC(F)Oc1ccc(-c2nnc3cncc(OCC(F)(F)F)n23)cc1</smiles>

3

\section{$t$-butyl peracetate ( 3 eq.) \\ $2 \mathrm{~mol} \%\left[\operatorname{lr}\left(\mathrm{df}-\mathrm{CF}_{3}-\mathrm{ppy}\right)_{2}\right.$ (dtbpy)]PF 1:1 TFA:ACN \\ Blue light, $16 \mathrm{~h}$}<smiles>[Z10]c1ncc(OCC(F)(F)F)n2c(-c3ccc(OC(F)F)cc3)nnc12</smiles><smiles>C[Si](C)(C)CCOc1cncc2nnc(-c3ccc(OC(F)F)cc3)n12</smiles>

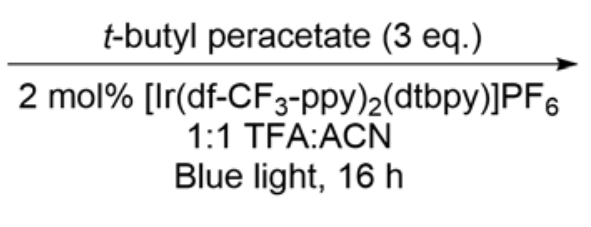<smiles>Cc1ncc(OCC[Si](C)(C)C)n2c(-c3ccc(OC(F)F)cc3)nnc12</smiles>

reaction unsuccessful<smiles>FC(F)Oc1ccc(-c2nnc3cncc(OCCc4ccccc4)n23)cc1</smiles>

2

\section{$t$-butyl peracetate ( 3 eq.) \\ $2 \mathrm{~mol} \%\left[\mathrm{Ir}\left(\mathrm{df}-\mathrm{CF}_{3}-\mathrm{ppy}\right)_{2}(\mathrm{dtbpy})\right] \mathrm{PF}_{6}$ 1:1 TFA:ACN}

Blue light, $12 \mathrm{~h}$<smiles>Cc1ncc(OCCc2ccccc2)n2c(-c3ccc(OC(F)F)cc3)nnc12</smiles>

$13(43 \%)$

Scheme 5. Photoredox-catalyzed methylation of the scaffolds 2, 3, and 5.

The structures of all synthesized methylated products were determined using 1D/2D NMR and HRMS (see Supplementary Materials). An example of full characterization for $\mathbf{1 3}$ is given below. Compound $\mathbf{1 3}$ was purified as a clear film and was assigned the molecular formula $\mathrm{C}_{21} \mathrm{H}_{19} \mathrm{~F}_{2} \mathrm{~N}_{4} \mathrm{O}_{2}$ following analysis of HRESMS ion at $\mathrm{m} / \mathrm{z} 397.1470$ $[\mathrm{M}+\mathrm{H}]^{+}$. The ${ }^{1} \mathrm{H}$ NMR spectrum of $\mathbf{1 3}$ in DMSO- $d_{6}$ (Table 2) indicated the presence of two methylenes [ $\delta_{\mathrm{H}} 2.86(\mathrm{H}-22)$ and $\left.4.42(\mathrm{H}-21)\right], 10$ aromatic protons $\left[\delta_{\mathrm{H}} 7.39(\mathrm{H}-6)\right.$, $\delta_{\mathrm{H}} 7.74(\mathrm{H}-11$ and $\mathrm{H}-15), 7.29(\mathrm{H}-12$ and $\mathrm{H}-14), \delta_{\mathrm{H}} 6.90(\mathrm{H}-24$ and $\mathrm{H}-28), 7.17(\mathrm{H}-25$ and $\mathrm{H}-27), 7.16(\mathrm{H}-26)]$, and a methyl singlet $\left[\delta_{\mathrm{H}} 2.72(\mathrm{H}-29)\right]$. The ${ }^{1} J_{\mathrm{H}-\mathrm{F}}$ splitting of a triplet $(73.7 \mathrm{~Hz})$ was used to identify the proton located in the difluoromethoxy group $\left[\delta_{\mathrm{H}} 7.36\right.$ (H-17)]. Analysis of the COSY system allowed for two aromatic systems to be distinguished, with four aromatic protons $\left[\delta_{\mathrm{H}} 7.74(\mathrm{H}-11\right.$ and $\mathrm{H}-15)$ and $7.29(\mathrm{H}-12$ and $\left.\mathrm{H}-14)\right]$ belonging to one system and five aromatic protons $\left[\delta_{\mathrm{H}} 6.90(\mathrm{H}-24\right.$ and $\mathrm{H}-28), 7.17(\mathrm{H}-25$ and $\mathrm{H}-27)$, and $7.16(\mathrm{H}-26)]$ belonging to the other. 
Table 2. NMR data for compound 13 in DMSO- $d_{6}{ }^{\text {a }}$.

\begin{tabular}{|c|c|c|c|c|c|}
\hline Position & $\begin{array}{l}{ }_{\mathrm{H}}, \text { mult., } J \\
\text { in } \mathrm{Hz} \text {, int }\end{array}$ & $\begin{array}{l}{ }^{13} \text { C, mult., } J \\
\text { in } \mathrm{Hz}\end{array}$ & COSY & НМВС & ROESY \\
\hline 3 & & $146.3, \mathrm{~s}$ & & & \\
\hline 5 & & $142.8, \mathrm{~s}$ & & & \\
\hline 6 & $7.39, \mathrm{~s}, 1 \mathrm{H}$ & $107.9, \mathrm{~s}$ & & 5,8 & \\
\hline 8 & & $143.2, \mathrm{~s}$ & & & \\
\hline 9 & & $146.8, \mathrm{~s}$ & & & \\
\hline 10 & & $124.8, \mathrm{~s}$ & & & \\
\hline 11 & $7.74, \mathrm{~m}, 1 \mathrm{H}$ & $132.6, \mathrm{~s}$ & 12 & $3,13,15$ & 12 \\
\hline 12 & $7.29, \mathrm{~m}, 1 \mathrm{H}$ & 117.6, s & 11 & 10,14 & 11 \\
\hline 13 & & $152.0, t, 3.2$ & & & \\
\hline 14 & $7.29, \mathrm{~m}, 1 \mathrm{H}$ & $117.6, \mathrm{~s}$ & 15 & 10,12 & 15 \\
\hline 15 & $7.74, \mathrm{~m}, 1 \mathrm{H}$ & $132.6, \mathrm{~s}$ & 14 & $3,11,13$ & 14 \\
\hline 17 & $7.36, t, 73.7,1 \mathrm{H}$ & $116.2, t, 258.2$ & & 13 & \\
\hline 21 & $4.42, \mathrm{t}, 6.5,2 \mathrm{H}$ & $71.0, \mathrm{~s}$ & 22 & $5,22,23$ & 6,22 \\
\hline 22 & $2.86, t, 6.5,2 \mathrm{H}$ & $33.9, \mathrm{~s}$ & 21 & $21,23,24,28$ & $21,24,28$ \\
\hline 23 & & $137.4, \mathrm{~s}$ & & & \\
\hline 24 & $6.90, \mathrm{~m}, 1 \mathrm{H}$ & $128.7, \mathrm{~s}$ & 25 & $22,26,28$ & 25 \\
\hline 25 & $7.17, \mathrm{~m}, 1 \mathrm{H}$ & $128.2, \mathrm{~s}$ & & 23,27 & \\
\hline 26 & $7.16, \mathrm{~m}, 1 \mathrm{H}$ & $126.4, \mathrm{~s}$ & $\begin{array}{l}24,26 \\
25,27\end{array}$ & 24,28 & $\begin{array}{l}24,26 \\
25,27\end{array}$ \\
\hline 27 & $7.17, \mathrm{~m}, 1 \mathrm{H}$ & $128.2, \mathrm{~s}$ & 25,27 & 23,25 & 25,27 \\
\hline 28 & $6.90, \mathrm{~m}, 1 \mathrm{H}$ & 128.7, s & 26,28 & $22,24,26$ & 26,28 \\
\hline 29 & $2.72, \mathrm{~s}, 3 \mathrm{H}$ & 19.7, s & 27 & $6,8,9$ & 27 \\
\hline
\end{tabular}

a Recorded at $500 \mathrm{MHz}\left({ }^{1} \mathrm{H}\right.$ NMR $)$ and $125 \mathrm{MHz}\left({ }^{13} \mathrm{C}\right.$ NMR $)$ at $25^{\circ} \mathrm{C}$.

The ${ }^{13} \mathrm{C}$ NMR spectrum revealed a ${ }^{3} J_{C-F}$ triplet splitting $(3.2 \mathrm{~Hz})$ for $\delta_{C} 152.0$, which allowed the assignment of $\mathrm{C}-13$. This was supported by the HMBC correlation observed from the difluoromethoxy proton $\delta_{\mathrm{H}} 7.36$ to $\delta_{\mathrm{C}}$ 152.0. Furthermore, $\mathrm{HMBC}$ correlations of $\mathrm{H}-12$ and $\mathrm{H}-14$ to $\delta_{\mathrm{C}} 124.8(\mathrm{C}-10)$ and $\mathrm{H}-11$ and $\mathrm{H}-15$ to $\delta_{\mathrm{C}} 152.0(\mathrm{C}-13)$ and $\delta_{\mathrm{C}} 146.3$ confirmed that this ring system attached to the triazolo ring at position 3 .

The presence of phenyl ether sidechain was supported by the HMBC correlations from the aromatic protons $\delta_{\mathrm{H}} 6.90$ to $\delta_{\mathrm{C}} 33.9(\mathrm{C}-22)$, and $\delta_{\mathrm{H}} 4.42$ to $\delta_{\mathrm{C}} 137.4(\mathrm{C}-23)$ and $\delta_{\mathrm{C}}$ 142.8 (C-5) of the pyrazine ring. This was further supported by a strong ROE correlation from $\mathrm{H}-6\left(\delta_{\mathrm{H}} 7.39\right)$ to the methylene at $\mathrm{H}-21\left(\delta_{\mathrm{H}} 4.42\right)$. The methyl group protons $\mathrm{H}-29$ showed a two-bond HMBC to the C-8 position and a three-bond HMBC to C-9 $\left(\delta_{\mathrm{C}} 146.8\right)$, confirming its position on the triazolopyrazine core. Key COSY, HMBC, and ROESY correlations for compound $\mathbf{1 3}$ are shown in Figure 5.

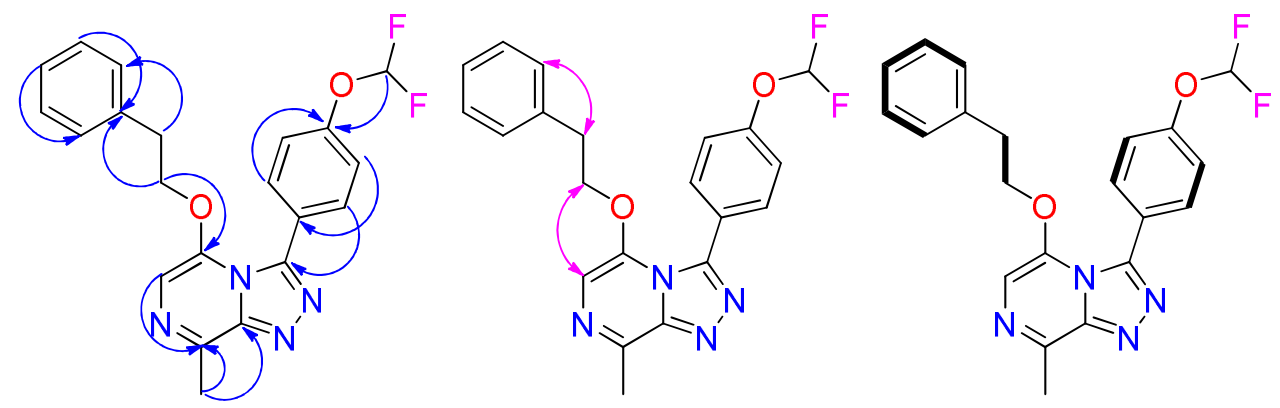

Figure 5. Key $\operatorname{HMBC}(\rightarrow)$, ROESY $(\leftrightarrow)$, and COSY $(-)$ correlations for 13.

\subsection{Late-Stage Functionalization Using Baran Diversinates ${ }^{\mathrm{TM}}$}

The goal was to add a series of fluoroalkyl groups to the 8-position of the triazolopyrazine scaffold 7 using Diversinate ${ }^{\mathrm{TM}}$ chemistry. To this end, a method was adapted from Kuttruff et al., where a solvent system of 1:1 $\mathrm{CH}_{2} \mathrm{Cl}_{2} / \mathrm{DMSO}$ was used along with a Diversinate $^{\mathrm{TM}}$ salt, the oxidant tert-butylhydroperoxide (TBHP), and TFA, since protona- 
tion of the pyrazine nitrogen adjacent to position 8 was expected to facilitate the radical addition [20].

The Diversinate ${ }^{\mathrm{TM}}$ reagents investigated were zinc trifluoromethanesulfinate (TFMS) sodium 1,1-difluoroethanesulfinate (DFES), sodium 4,4-difluorocyclohexanesulfinate (DFHS), and sodium 1-(trifluoromethyl)cyclopropanesulfonate (TFCS). The reaction was carried out as follows: a mixture of the scaffold 7 , Diversinate ${ }^{\mathrm{TM}}$ (2 eq.), and TFA (5 eq.) in DMSO $/ \mathrm{CH}_{2} \mathrm{Cl}_{2} / \mathrm{H}_{2} \mathrm{O}$ (5:5:2) was stirred for $30 \mathrm{~min}$ at room temperature and then cooled to $4{ }^{\circ} \mathrm{C}$. Aqueous TBHP ( $70 \%, 3$ eq.) was then added over five minutes and stirring continued for $1 \mathrm{~h}$ before slowly warming to rt with stirring for a further $16 \mathrm{~h}$. The reaction mixture was then dried under vacuum, and products were isolated and purified using $\mathrm{C}_{18} \mathrm{HPLC}\left(\mathrm{MeOH} / \mathrm{H}_{2} \mathrm{O} / 0.1 \%\right.$ TFA) This methodology was successful with three of the four Diversinates ${ }^{\mathrm{TM}}$ (Scheme 6), with only the TFCS reaction failing to produce a product. Two of the products were unexpected. These were the 5-dechlorinated products 16 and 18.<smiles>Clc1ccc(-c2nnc3cncc(Cl)n23)cc1</smiles>

7

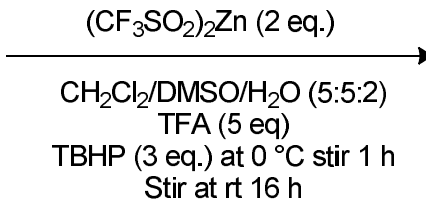

Stir at $\mathrm{rt} 16 \mathrm{~h}$<smiles>FC(F)(F)c1ncc(Cl)n2c(-c3ccc(Cl)cc3)nnc12</smiles>

$14(19 \%)$<smiles>Clc1ccc(-c2nnc3cncc(Cl)n23)cc1</smiles>

7

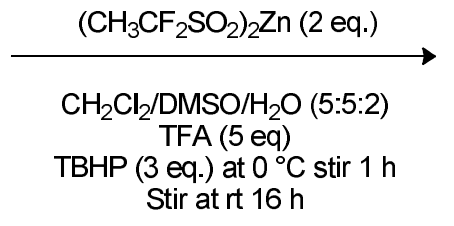<smiles>CC(F)(F)c1ncc(Cl)n2c(-c3ccc(Cl)cc3)nnc12</smiles>

$15(15 \%)$<smiles>CC(F)(F)c1nccn2c(-c3ccc(Cl)cc3)nnc12</smiles>

$16(17 \%)$<smiles>Clc1ccc(-c2nnc3cncc(Cl)n23)cc1</smiles>

7

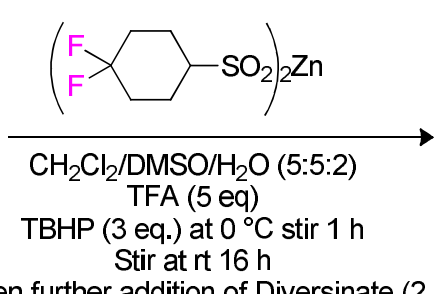

Then further addition of Diversinate $(2$ eq.) and TBHP ( 2 eq.) and stir for $24 \mathrm{~h}$

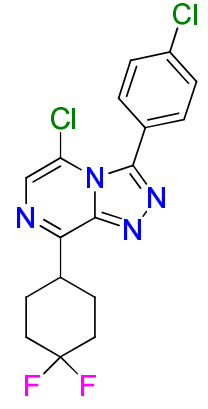

$17(22 \%)$<smiles>FC1(F)CCC(c2nccn3c(-c4ccc(Cl)cc4)nnc23)CC1</smiles>

$18(22 \%)$

Scheme 6. Introduction of fluoroalkyl groups via Diversinate ${ }^{\mathrm{TM}}$ chemistry.

A mechanism for the formation of these dechlorinated products is suggested in Scheme 7. For example, addition of the 1,1-dichloroethyl radical to the scaffold 7 would generate the radical 19. As 19 is stabilized by resonance, it could achieve a sufficient concentration to undergo a radical disproportionation reaction whereby the radical center of one molecule of 19 abstracts a hydrogen atom from a second molecule of 19 to generate a molecule of product $\mathbf{1 5}$ and the dihydro intermediate 20 . Loss of $\mathrm{HCl}$ (water could act as a base here) from 20 generates the 5-dechlorinated product 16. Compelling evidence for this mechanism is that it predicts equal amounts of $\mathbf{1 5}$ and $\mathbf{1 6}$ and equal amounts of 
17 and 18 , as found. What is not clear is why the formation of $\mathbf{1 4}$ was not accompanied by formation of the corresponding 5-dechlorinated product. Possibly the mechanism of formation of $\mathbf{1 4}$ did not involve disproportionation, but instead involved hydrogen atom abstraction by the $\mathrm{CF}_{3}$ radical (the $\mathrm{CF}_{3}$ radical would be expected to be more electrophilic than the other two fluoroalkyl radicals).
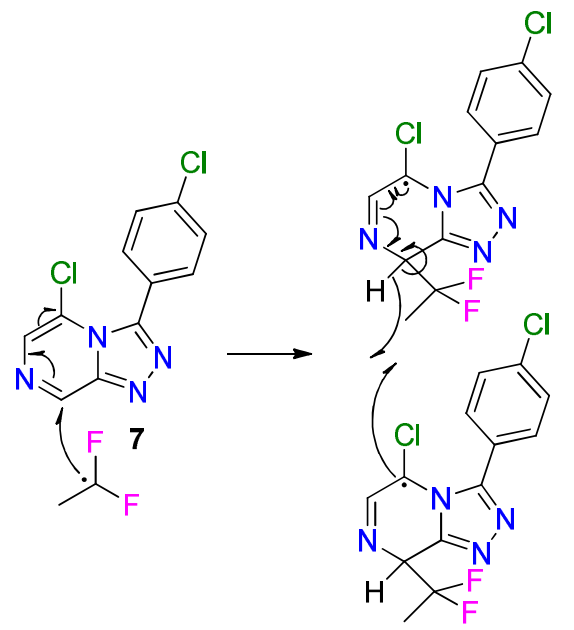

19

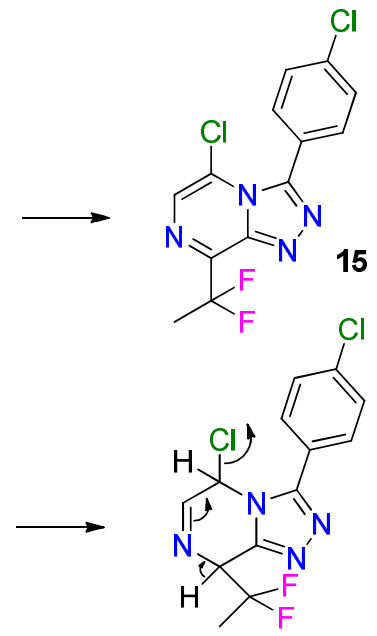

20

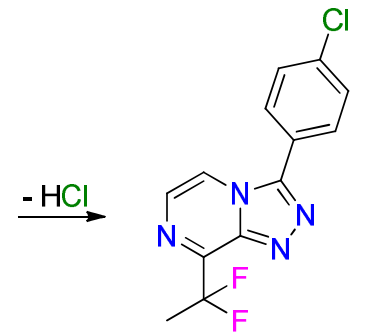

16

Scheme 7. Proposed mechanism for the formation of compound $\mathbf{1 5}$ and dechlorinated product $\mathbf{1 6 .}$

The products 14-18 were characterized by 1D/2D NMR and HRMS, and the structure of $\mathbf{1 8}$ was confirmed by X-ray crystal structure determination (see Supplementary Materials). Furthermore, during $\mathrm{C}_{18}$ HPLC purification of the Diversinate ${ }^{\mathrm{TM}}$ reactions described above, a small amount of X-ray quality crystalline starting material (7) was obtained. The ORTEP of compounds $\mathbf{7}$ and $\mathbf{1 8}$ are shown below in Figure 6.
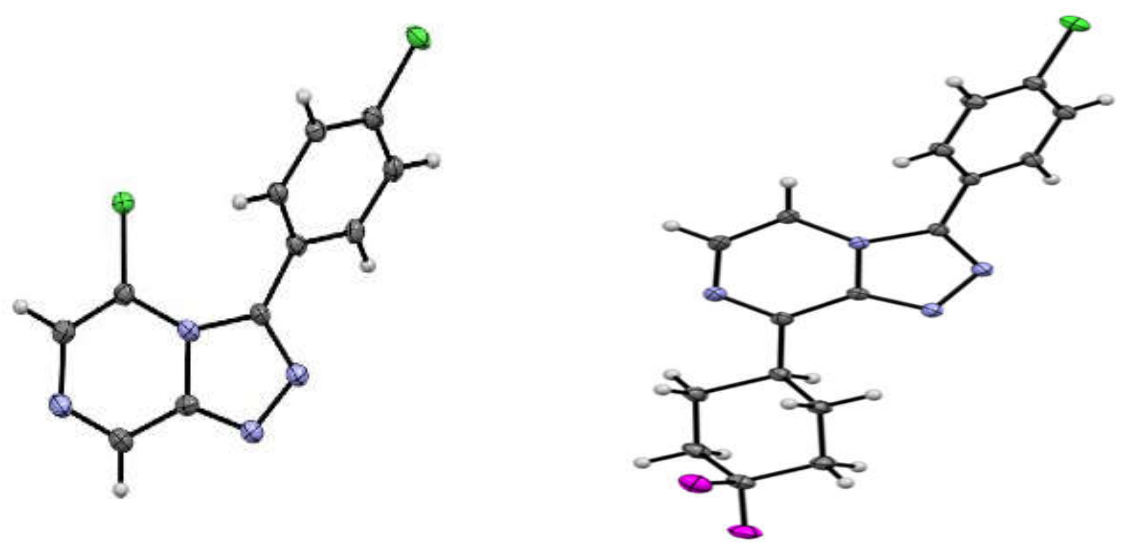

Figure 6. ORTEP drawing of compounds 7 and 18.

\subsection{Bioactivity and Preliminary SAR}

Using the software DataWarrior ${ }^{\circledR}$ [21], all compounds were found to have no violations of Lipinski's "Rule of Five" in silico, suggesting the base requirement for orally active drug-like compounds was met [22]. The semisynthesized/functionalized triazolopyrazine compounds and the scaffold triazolopyrazine precursors, compounds 1-18, were tested for their antimalarial activity against the 3D7 (chloroquine-sensitive strain) and Dd2 (chloroquine, pyrimethamine, and mefloquine resistant strain) P. falciparum [23]. Where an accurate $\mathrm{IC}_{50}$ value could not be determined due to $100 \%$ growth inhibition and a plateau not being reached, but where $\geq 90 \%$ growth inhibition was attained at the top screening concentration, an estimated $\mathrm{IC}_{50}$ value was calculated. Cytotoxicity data were also acquired for all 
scaffolds and synthesized compounds using a human embryonic kidney cell line (HEK293) (Table 3) [24], demonstrating that none of the compounds exhibited cytotoxicity against HEK293 cells when tested at concentrations up to $80 \mu \mathrm{M}$.

Table 3. Biological data for triazolopyrazines 1-18.

\begin{tabular}{|c|c|c|c|c|}
\hline Compounds & $\begin{array}{c}P f 3 \mathrm{D} 7^{\mathrm{a}} \\
\mathrm{IC}_{50} \pm \mathrm{SD} \mu \mathrm{M}\end{array}$ & $\begin{array}{c}\text { Pf Dd2 }{ }^{\mathrm{b}} \\
\mathrm{IC}_{50} \pm \mathrm{SD} \mu \mathrm{M}\end{array}$ & SI for $3 D 7^{c}$ & SI for $\operatorname{Dd} 2^{c}$ \\
\hline 1 & $16.81 \pm 1.25^{\mathrm{d}}$ & $22.81 \pm 13.73$ & $>4$ & $>3$ \\
\hline 2 & $0.31 \pm 0.01$ & $0.54 \pm 0.02$ & $>258$ & $>148$ \\
\hline 3 & $16.65 \pm 1.02$ & $21.24 \pm 5.41$ & $>4$ & $>3$ \\
\hline 4 & $\mathrm{e}$ & NA & - & - \\
\hline 5 & $13.86 \pm 0.87$ & NA & $>5$ & - \\
\hline 6 & e & NA & - & - \\
\hline 7 & $12.62 \pm 1.90$ & $14.32 \pm 0.62$ & $>6$ & $>5$ \\
\hline 8 & $19.18 \pm 0.28^{\mathrm{d}}$ & $32.39 \pm 1.44$ & $>4$ & $>2$ \\
\hline 9 & $18.89 \pm 0.66^{\mathrm{d}}$ & $25.87 \pm 0.74$ & $>4$ & $>3$ \\
\hline 10 & $27.33 \pm 0.82^{d}$ & $38.25 \pm 0.61$ & $>2$ & $>2$ \\
\hline 11 & $12.49 \pm 0.58$ & $31.22 \pm 0.82$ & $>6$ & $>2$ \\
\hline 12 & $27.33 \pm 0.82^{\mathrm{d}}$ & e & $>2$ & \\
\hline 13 & $11.01 \pm 0.56^{\mathrm{d}}$ & $8.20 \pm 0.60$ & $>7$ & $>9$ \\
\hline 14 & $4.84 \pm 0.13$ & $6.18 \pm 0.09$ & $>16$ & $>12$ \\
\hline 15 & $1.72 \pm 0.02$ & $2.58 \pm 0.07$ & $>46$ & $>31$ \\
\hline 16 & $6.40 \pm 0.10$ & $24.70 \pm 0.15$ & $>12$ & $>3$ \\
\hline 17 & $20.19 \pm 2.86^{\mathrm{d}}$ & e & $>3$ & \\
\hline 18 & e & NA & - & - \\
\hline Controls & $\begin{array}{c}\text { Pf 3D7 }{ }^{\mathrm{a}} \\
\mathrm{IC}_{50} \pm \mathrm{SD} \mathrm{nM}\end{array}$ & $\begin{array}{c}P f \mathrm{Dd} 2^{\mathrm{b}} \\
\mathrm{IC}_{50} \pm \mathrm{SD} \mathrm{nM}\end{array}$ & SI for $3 D 7^{c}$ & SI for $\mathrm{Dd} 2^{\mathrm{c}}$ \\
\hline Pyrimethamine & $12.08 \pm 0.04$ & $\mathrm{e}$ & $>331$ & - \\
\hline Artesunate & $3.48 \pm 0.14$ & $2.00 \pm 0.10$ & $>2874$ & $>5000$ \\
\hline Puromycin & $95.28 \pm 1.45$ & $101.00 \pm 2.80$ & 12 & 11 \\
\hline \multicolumn{5}{|c|}{ 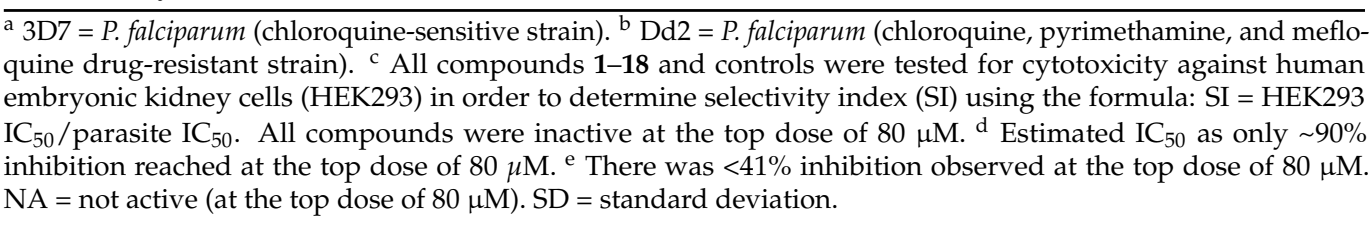 } \\
\hline
\end{tabular}

The scaffold compounds $\mathbf{1}, \mathbf{7}$, and $\mathbf{9}$, as well as $\mathbf{1 1}$, the methylated derivative of 1, exhibited poor activity against 3D7 P. falciparum, having the respective $\mathrm{IC}_{50}$ values of $16.8,12.6,18.9$, and $12.5 \mu \mathrm{M}$. While 11 retained comparable, if not minimally better, activity than $\mathbf{1}$, the other methylated scaffold derivatives $(\mathbf{8}$ and $\mathbf{1 0})$ experienced a reduction in antimalarial potency.

The ether compound 2, a known OSM compound, exhibited strong activity against the $P f$ 3D7 parasites with an $\mathrm{IC}_{50}$ value of $0.3 \mu \mathrm{M}$, which is in agreement with activities reported for other OSM participants [14]. Methylation of 2, generating compound 13, resulted in a 37-fold decrease in potency with an $\mathrm{IC}_{50}$ value of $11.1 \mu \mathrm{M}$. Compound 3 demonstrated a poor $\mathrm{IC}_{50}$ value of $16.7 \mu \mathrm{M}$ and its methylated ether derivative $12 \mathrm{did}$ not display $\geq 90 \%$ inhibition, so a predicted $\mathrm{IC}_{50}$ value was not calculated. This data indicates methylation at the C-8 position had a detrimental effect on antimalarial activity.

The Diversinate ${ }^{\mathrm{TM}}$ derivatives of compound 7 showed mixed results, with compounds 14, 15, and 16 showing an increase in potency over the parent scaffold compound 7 $\left(\mathrm{IC}_{50}=12.6 \mu \mathrm{M}\right)$, while the difluorocyclohexyl functionalized compounds 17 and 18 showed limited activity. Of the Diversinate ${ }^{\mathrm{TM}}$ derivatives made during these studies, compound 15 $\left(\mathrm{IC}_{50}=1.7 \mu \mathrm{M}\right)$, which exhibited a 7.3-fold improvement in potency compared to the parent scaffold (7), identified the difluoroethane moiety as a promising functional group that should be applied to other promising leads within the OSM project. Furthermore, with over 
30 Diversinate $^{\mathrm{TM}}$ reagents commercially available, we believe additional LSF investigations on OSM scaffolds using this chemistry are warranted.

The Dd2 data largely followed the same overall trend as the 3D7 results. However, the Dd2 antimalarial activity was reduced across all tested compounds with the exception of compound 13, which displayed a slight increase in potency when compared to the 3D7 results. Of note, compound 15 remained the most potent functionalized compound generated during these studies upon comparison of both the Dd2 and 3D7 data, while compounds $5,11,12,16$, and 17 displayed large decreases in potency when tested against the drugresistant strain.

\section{Materials and Methods}

\subsection{General Experimental Procedures}

NMR spectra were recorded on a Bruker Avance III $500 \mathrm{MHz}$ spectrometer (Zürich, Switzerland) equipped with a BBFO Smartprobe at $25{ }^{\circ} \mathrm{C}$. The ${ }^{1} \mathrm{H}$ and ${ }^{13} \mathrm{C}$ NMR chemical shifts were referenced to the solvent peak for DMSO- $d_{6}\left(\delta_{\mathrm{H}} 2.50\right.$ and $\left.\delta_{\mathrm{C}} 39.52\right)$. A JASCO V-650 UV/Vis spectrophotometer (Tokyo, Japan) was used for recording UV spectra. LRESIMS data were recorded on a Thermo Fisher Scientific MSQ Plus single quadrupole mass spectrometer (Waltham, MA, USA). HRESIMS data were acquired on a Bruker maXis II ETD ESI-qTOF (Bremen, Germany). An open glass column $(25 \mathrm{~mm} \times 80 \mathrm{~mm})$ with sintered glass frit and tap was packed with Merck silica gel (40-63 $\mu \mathrm{M}, 143 \AA$ ) (Darmstadt, Germany) and used for all silica flash columns. Alltech Davisil $\mathrm{C}_{18}$-bonded silica (35-75 $\mu \mathrm{M}, 150 \AA$ ) (Sydney, NSW, Australia) was used for pre-adsorption of crude reaction products then packed into an Alltech guard cartridge $(10 \mathrm{~mm} \times 30 \mathrm{~mm})$ (Sydney, NSW, Australia) in order to facilitate semipreparative HPLC. A Thermo Fisher Scientific Dionex Ultimate 3000 HPLC (Waltham, MA, USA) was used for semipreparative HPLC separations. TLC analysis was carried out using Merck silica gel $60 \mathrm{~F}_{254 \mathrm{~S}}$ aluminum plates (Darmstadt, Germany). A Thermo Electron $\mathrm{C}_{18}$-bonded silica Betasil column (5 $\mu \mathrm{M}, 143 \AA$, $21.2 \mathrm{~mm} \times 150 \mathrm{~mm}$ ) (Waltham, MA, USA) was used for semipreparative HPLC separation. All solvents used for chromatography, UV, and MS were Honeywell Burdick \& Jackson HPLC grade (Muskegon, MI, USA) or RCI Labscan HPLC grade (Bangkok, Thailand). $\mathrm{H}_{2} \mathrm{O}$ was Sartorius arium proVF (Göttingen, Germany) filtered. Synthetic reagents were purchased from Sigma-Aldrich (St. Louis, MO, USA) or AK Scientific Inc. (Union City, CA, USA) and used without further purification. A Kessil PR-160L-456 nm blue light lamp was used as a light source for the photoredox reactions. Kinesis clear glass vials and screw caps $(1.5 \mathrm{~mL})$ (Brisbane, QLD, Australia) and an Industrial Equipment \& Control Pty Ltd. stirrer hotplate were used for all photoredox and Diversinate ${ }^{\mathrm{TM}}$ reactions.

\subsection{General Procedure for Coupling of Primary Alcohol with Chloro-Heterocycle Scaffold}

The chloro-heterocycle scaffold $(1.70 \mathrm{mmol})$ and primary alcohol $(1 \mathrm{eq.}, 1.70 \mathrm{mmol})$ were dissolved in anhydrous toluene $(10 \mathrm{~mL})$, along with $\mathrm{KOH}(312 \mathrm{mg}$, $5.58 \mathrm{mmol}, 3.3 \mathrm{eq}$.) and 18-crown-6 ( $36 \mathrm{mg}, 0.14 \mathrm{mmol}, 0.08$ eq.). The reaction mixtures were subsequently stirred at $40{ }^{\circ} \mathrm{C}$ for 1 to $3 \mathrm{~h}$ with reactions monitored by TLC. Upon reaction completion, the mixture was diluted with $\mathrm{H}_{2} \mathrm{O}(60 \mathrm{~mL})$ and then extracted with EtOAc $(3 \times 20 \mathrm{~mL})$. The organic extracts were combined, dried $\left(\mathrm{Na}_{2} \mathrm{SO}_{4}\right)$, filtered, and concentrated under reduced pressure to give a crude product that was preadsorbed to silica $(\sim 1 \mathrm{~g})$, then purified by silica flash column chromatography using a 10\% stepwise gradient from 100\%n-hexane to $100 \%$ EtOAc (100 mL elutions), followed by final flushes with $10 \% \mathrm{MeOH} / 90 \% \mathrm{CH}_{2} \mathrm{Cl}_{2}$ $(100 \mathrm{~mL})$ and $20 \% \mathrm{MeOH} / 80 \% \mathrm{CH}_{2} \mathrm{Cl}_{2}(100 \mathrm{~mL})$. Fractions containing UV-active material, as deemed by TLC, were analyzed by ${ }^{1} \mathrm{H}$ NMR spectroscopy and LCMS, in order to identify products of interest; only fractions containing the desired product in high purity ( $>95 \%)$ were combined. 


\subsubsection{Compound 2}

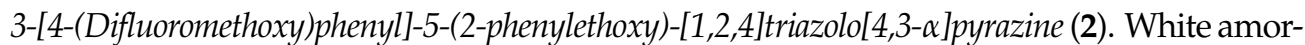
phous solid (125.4 mg, 33\%); UV (MeOH) $\lambda_{\max }(\log \varepsilon) 241$ (4.64), 286 (4.11), 315 (4.51) nm; ${ }^{1} \mathrm{H}$ NMR $\left(500 \mathrm{MHz}, \mathrm{DMSO}-d_{6}\right) \delta_{\mathrm{H}} 2.90(2 \mathrm{H}, \mathrm{t}, J=6.5 \mathrm{~Hz}, \mathrm{H}-22), 4.50(2 \mathrm{H}, \mathrm{t}, J=6.5 \mathrm{~Hz}$, H-21), 6.91 (2H, m, H-24, H-28), 7.16 (1H, m, H-26), 7.18 (2H, m, H-25, H-27), 7.30 (2H, m, H-12, H-14), $7.37\left(1 \mathrm{H}, \mathrm{t},{ }^{2} \mathrm{~J}_{\mathrm{HF}}=73.7 \mathrm{~Hz}, \mathrm{H}-17\right), 7.60(1 \mathrm{H}, \mathrm{s}, \mathrm{H}-6), 7.77(2 \mathrm{H}, \mathrm{m}, \mathrm{H}-$ 11, H-15), $9.04(1 \mathrm{H}, \mathrm{s}, \mathrm{H}-8) ;{ }^{13} \mathrm{C}$ NMR (125 MHz, DMSO-d $\left.{ }_{6}\right) \delta_{\mathrm{C}} 33.8$ (C-22), $71.2(\mathrm{C}-21)$, $108.8(\mathrm{C}-6), 116.2\left(\mathrm{t},{ }^{1} J_{\mathrm{CF}}=258.8 \mathrm{~Hz}, \mathrm{C}-17\right), 117.6(\mathrm{C}-12, \mathrm{C}-14), 124.7(\mathrm{C}-10), 126.3(\mathrm{C}-26)$, 128.3 (C-24, C-28), 128.6 (C-25, C-27), 132.6 (C-11, C-15), 135.0 (C-8), 137.3 (C-23), 145.5 (C-3), $143.8(\mathrm{C}-5), 147.4(\mathrm{C}-9), 152.0\left(\mathrm{t},{ }^{3} J_{\mathrm{CF}}=3.2 \mathrm{~Hz}, \mathrm{C}-13\right)$; (+)-LRESIMS $\mathrm{m} / \mathrm{z}$ (rel. int.) $383(100)[\mathrm{M}+\mathrm{H}]^{+}, 765(30)[2 \mathrm{M}+\mathrm{H}]^{+} ;(+)$-HRESIMS $\mathrm{m} / z 383.1315[\mathrm{M}+\mathrm{H}]^{+}$(calcd for $\mathrm{C}_{20} \mathrm{H}_{17} \mathrm{~F}_{2} \mathrm{~N}_{4} \mathrm{O}_{2}, 383.1314$ ), $405.1133[\mathrm{M}+\mathrm{Na}]^{+}$(calcd for $\mathrm{C}_{20} \mathrm{H}_{16} \mathrm{~F}_{2} \mathrm{~N}_{4} \mathrm{NaO}_{2}, 405.1134$ ).

\subsubsection{Compound 3}

3-[(4-Difluoromethoxy)phenyl]-5-(2,2,2,-trifluroethoxy)-[1,2,4]triazolo[4,3- $\alpha]$ pyrazine (3). White amorphous solid (105.3 mg, 17\%); mp 169-170 ${ }^{\circ} \mathrm{C} ; \mathrm{UV}(\mathrm{MeOH}) \lambda_{\max }(\log \varepsilon) 239$ (4.95), $282(4.54), 311(4.48) \mathrm{nm} ;{ }^{1} \mathrm{H}$ NMR $\left(500 \mathrm{MHz}, \mathrm{DMSO}-d_{6}\right) \delta_{\mathrm{H}} 5.05\left(2 \mathrm{H}, \mathrm{q}^{2}{ }^{2} \mathrm{~J}_{\mathrm{HF}}=8.5 \mathrm{~Hz}, \mathrm{H}-21\right)$, $7.29(2 \mathrm{H}, \mathrm{m}, \mathrm{H}-12, \mathrm{H}-14), 7.35\left(1 \mathrm{H}, \mathrm{t},{ }^{2} \mathrm{~J}_{\mathrm{HF}}=73.8 \mathrm{~Hz}, \mathrm{H}-17\right), 7.69(1 \mathrm{H}, \mathrm{s}, \mathrm{H}-6), 7.79(2 \mathrm{H}, \mathrm{m}$, H-11, H-15), $9.15(1 \mathrm{H}, \mathrm{s}, \mathrm{H}-8) ;{ }^{13} \mathrm{C}$ NMR $\left(125 \mathrm{MHz}, \mathrm{DMSO}-d_{6}\right) \delta_{\mathrm{C}} 66.1\left(\mathrm{q},{ }^{2} J_{\mathrm{CF}}=36.2 \mathrm{~Hz}, \mathrm{C}-\right.$ 21), $109.7(\mathrm{C}-6), 116.1\left(\mathrm{t},{ }^{1} J_{\mathrm{CF}}=258.8 \mathrm{~Hz}, \mathrm{C}-17\right), 117.7(\mathrm{C}-12, \mathrm{C}-14), 122.6\left(\mathrm{q},{ }^{1} J_{\mathrm{CF}}=277.2 \mathrm{~Hz}\right.$, C-22), 124.4 (C-10), 132.4 (C-11, C-15), 136.8 (C-8), 142.6 (C-5), 145.7 (C-3), 147.4 (C-9), $152.0\left(\mathrm{t},{ }^{3} J_{\mathrm{CF}}=3.3 \mathrm{~Hz}, \mathrm{C}-13\right)$; (+)-LRESIMS $\mathrm{m} / \mathrm{z}$ (rel. int.) $361(100)[\mathrm{M}+\mathrm{H}]^{+}$; (+)-HRESIMS $m / z 383.0536[\mathrm{M}+\mathrm{H}]^{+}$(calcd for $\mathrm{C}_{14} \mathrm{H}_{9} \mathrm{~F}_{5} \mathrm{~N}_{4} \mathrm{NaO}_{2}, 383.0538$ ).

\subsubsection{Compound 4}

3-[4-(Difluoromethoxy)phenyl]-[1,2,4]triazolo[4,3- $\alpha]$ pyrazin-8-ol (4). Beige amorphous solid (28.7 mg, 6\%); UV (MeOH) $\lambda_{\max }(\log \varepsilon) 247$ (4.83), $293(4.26) \mathrm{nm} ;{ }^{1} \mathrm{H}$ NMR $(500 \mathrm{MHz}$, DMSO- $\left.d_{6}\right) \delta_{\mathrm{H}} 6.92(1 \mathrm{H}, \mathrm{d}, J=5.8 \mathrm{~Hz}, \mathrm{H}-6), 7.40\left(1 \mathrm{H}, \mathrm{t},{ }^{2} J_{\mathrm{HF}}=73.6 \mathrm{~Hz}, \mathrm{H}-17\right), 7.42(2 \mathrm{H}, \mathrm{m}$, H-12, H-14), 7.43 (1H, d, J = 5.8 Hz, H-5), 7.91 (2H, m, H-11, H-15), 11.48 (1H, br s, H-20); ${ }^{13} \mathrm{C}$ NMR $\left(125 \mathrm{MHz}, \mathrm{DMSO}-d_{6}\right) \delta_{\mathrm{C}} 103.9(\mathrm{C}-5), 116.1\left(\mathrm{t},{ }^{1} J_{\mathrm{CF}}=258.7 \mathrm{~Hz}, \mathrm{C}-17\right), 118.7(\mathrm{C}-6)$, 119.2 (C-12, C-14), 122.6 (C-10), 130.4 (C-11, C-15), $145.3(\mathrm{C}-9), 152.5\left(\mathrm{t},{ }^{3} J_{\mathrm{CF}}=3.3 \mathrm{~Hz}\right.$, C-13), 153.0 (C-8); (+)-LRESIMS m/z (rel. int.) 279 (100) [M + H] ; (+)-HRESIMS m/z $279.0688[\mathrm{M}+\mathrm{H}]^{+}$(calcd for $\left.\mathrm{C}_{12} \mathrm{H}_{9} \mathrm{~F}_{2} \mathrm{~N}_{4} \mathrm{O}_{2}, 279.0688\right)$, $301.0507[\mathrm{M}+\mathrm{Na}]^{+}$(calcd for $\mathrm{C}_{12} \mathrm{H}_{8} \mathrm{~F}_{2} \mathrm{~N}_{4} \mathrm{NaO}_{2}$, 301.0508).

\subsubsection{Compound 5}

3-[4-(Difluoromethoxy)phenyl]-5-[2-trimethylsilyl)ethoxy]-[1,2,4]triazolo[4,3- $\alpha$ ]pyrazine (5). Brown crystals (153.2 mg, 24\%); mp $135^{\circ} \mathrm{C}$; UV (MeOH) $\lambda_{\max }(\log \varepsilon) 243$ (4.48), 317 (3.96) $\mathrm{nm} ;{ }^{1} \mathrm{H}$ NMR (500 MHz, DMSO-d $\left.d_{6}\right) \delta_{\mathrm{H}} 0.07(9 \mathrm{H}, \mathrm{s}, \mathrm{H}-24, \mathrm{H}-25, \mathrm{H}-26), 0.91(2 \mathrm{H}, \mathrm{m}, \mathrm{H}-22)$, $4.33(2 \mathrm{H}, \mathrm{m}, \mathrm{H}-21), 7.31(2 \mathrm{H}, \mathrm{m}, \mathrm{H}-12, \mathrm{H}-14), 7.36\left(1 \mathrm{H}, \mathrm{t},{ }^{2} J_{\mathrm{HF}}=73.6 \mathrm{~Hz}, \mathrm{H}-17\right), 7.59(1 \mathrm{H}$, $\mathrm{s}, \mathrm{H}-6), 7.81(2 \mathrm{H}, \mathrm{m}, \mathrm{H}-11, \mathrm{H}-15), 9.01(1 \mathrm{H}, \mathrm{s}, \mathrm{H}-8) ;{ }^{13} \mathrm{C}$ NMR $\left(125 \mathrm{MHz}, \mathrm{DMSO}-d_{6}\right) \delta_{\mathrm{C}}$ -1.7 (C-24, C-25, C-26), 16.5 (C-22), 69.4 (C-21), 109.1 (C-6), 116.1 (t, $\left.{ }^{1} J_{\mathrm{CF}}=258.3 \mathrm{~Hz}, \mathrm{C}-17\right)$, 117.6 (C-12, C-14), 124.8 (C-10), 132.8 (C-11, C-15), 134.7 (C-8), 143.9 (C-5), 147.5 (C-9), $145.6(\mathrm{C}-3), 151.9\left(\mathrm{t},{ }^{3} J_{\mathrm{CF}}=3.3 \mathrm{~Hz}, \mathrm{C}-13\right)$; (+)-LRESIMS $\mathrm{m} / \mathrm{z}$ (rel. int.) $379(26)[\mathrm{M}+\mathrm{H}]^{+}$, $675(60)[2 \mathrm{M}+\mathrm{H}]^{+} ;(+)$-HRESIMS $\mathrm{m} / \mathrm{z} 379.1396[\mathrm{M}+\mathrm{H}]^{+}$(calcd for $\mathrm{C}_{17} \mathrm{H}_{21} \mathrm{~F}_{2} \mathrm{~N}_{4} \mathrm{O}_{2} \mathrm{Si}$, 379.1396), $401.1216[\mathrm{M}+\mathrm{Na}]^{+}$(calcd for $\mathrm{C}_{17} \mathrm{H}_{20} \mathrm{~F}_{2} \mathrm{~N}_{4} \mathrm{NaO}_{2} \mathrm{Si}, 401.1216$ ).

\subsubsection{Compound 6}

3-[4-(Difluoromethoxy)phenyl]-8-[2-(trimethylsilyl)ethoxy)-[1,2,4]triazolo[4,3- $\alpha$ ]pyrazine (6). White amorphous solid (153.0 mg, 24\%); UV (MeOH) $\lambda_{\max }(\log \varepsilon) 243$ (4.73), 276 (4.43) nm; ${ }^{1} \mathrm{H}$ NMR $\left(500 \mathrm{MHz}, \mathrm{DMSO}-d_{6}\right) \delta_{\mathrm{H}} 0.11(9 \mathrm{H}, \mathrm{s}, \mathrm{H}-24, \mathrm{H}-25, \mathrm{H}-26), 1.24(2 \mathrm{H}, \mathrm{m}, \mathrm{H}-22), 4.65(2 \mathrm{H}$, $\mathrm{m}, \mathrm{H}-21), 7.41\left(1 \mathrm{H}, \mathrm{t},{ }^{2} J_{\mathrm{HF}}=73.7 \mathrm{~Hz}, \mathrm{H}-17\right), 7.43(2 \mathrm{H}, \mathrm{m}, \mathrm{H}-12, \mathrm{H}-14), 7.47(1 \mathrm{H}, \mathrm{d}, J=4.9 \mathrm{~Hz}$, H-6), $7.98(2 \mathrm{H}, \mathrm{m}, \mathrm{H}-11, \mathrm{H}-15), 8.17(1 \mathrm{H}, \mathrm{d}, J=4.9 \mathrm{~Hz}, \mathrm{H}-5) ;{ }^{13} \mathrm{C}$ NMR $\left(125 \mathrm{MHz}, \mathrm{DMSO}-d_{6}\right)$ $\delta_{\mathrm{C}}-1.3(\mathrm{C}-24, \mathrm{C}-25, \mathrm{C}-26), 16.8(\mathrm{C}-22), 65.2(\mathrm{C}-21), 111.9(\mathrm{C}-5), 116.1\left(\mathrm{t},{ }^{1} J_{\mathrm{CF}}=258.4 \mathrm{~Hz}, \mathrm{C}-17\right)$, 
119.2 (C-12, C-14), 122.7 (C-10), 130.2 (C-11, C-15), 139.9 (C-9), $152.4\left(\mathrm{t},{ }^{3} J_{\mathrm{CF}}=3.3 \mathrm{~Hz}\right.$, C-13), 153.3 (C-8); (+)-LRESIMS $\mathrm{m} / \mathrm{z}$ (rel. int.) $379(100)\left[\mathrm{M}+\mathrm{H}^{+}\right.$; (+)-HRESIMS $\mathrm{m} / \mathrm{z}$ $379.1397[\mathrm{M}+\mathrm{H}]^{+}$(calcd for $\left.\mathrm{C}_{17} \mathrm{H}_{21} \mathrm{~F}_{2} \mathrm{~N}_{4} \mathrm{O}_{2} \mathrm{Si}, 379.1396\right)$ ), $401.1216[\mathrm{M}+\mathrm{Na}]^{+}$(calcd for $\mathrm{C}_{17} \mathrm{H}_{20} \mathrm{~F}_{2} \mathrm{~N}_{4} \mathrm{NaO}_{2} \mathrm{Si}$, 401.1216).

\subsection{General Procedure for Photoredox Catalysis Methylation of Heterocyclic Scaffolds}

The photocatalyst ([Ir(dF-CF - -ppy $\left.\left.)_{2}\left(\mathrm{dtbpy}_{\mathrm{H}}\right)\right] \mathrm{PF}_{6}\right)(2.3 \mathrm{mg}, 0.002 \mathrm{mmol}, 0.02$ eq. $)$, heterocyclic scaffold $(0.1 \mathrm{mmol})$ and solvent $(1 \mathrm{~mL})$ (1:1 ACN:TFA), was added to a clear, glass vial and the solution was degassed using nitrogen for $3 \mathrm{~min}$. Tert-butyl peracetate ( $96 \mu \mathrm{L}, 50 \%$ solution in mineral spirits, $0.3 \mathrm{mmol}, 3.0$ eq.) was added and the reaction vial was positioned on top of a light intensity map that was attached to the top of the stirrer hotplate. A calibrated blue light lamp (Kessil PR-160L-456nm) was then aimed at the reaction vial in relation to the intensity $\operatorname{map}\left(15 \mathrm{~W} / \mathrm{cm}^{2}\right.$ to $\left.300 \mathrm{~W} / \mathrm{cm}^{2}\right)$. Compounds 8 and 10 were generated using a blue light intensity of $45 \mathrm{~W} / \mathrm{cm}^{2}$, while compounds 11, 12, and 13 were produced using $20 \mathrm{~W} / \mathrm{cm}^{2}$. All reactions were stirred and irradiated for $16 \mathrm{~h}$ at room temperature. Upon the completion of the reaction, the mixture was preadsorbed to $\mathrm{C}_{18}$-bonded silica ( 1 g) and then loaded into a guard cartridge that was subsequently attached to a semipreparative $\mathrm{C}_{18}$-bonded silica HPLC column. Isocratic conditions of $10 \%$ $\mathrm{MeOH} / 90 \% \mathrm{H}_{2} \mathrm{O}(0.1 \%$ TFA) were held for the first $10 \mathrm{~min}$, followed by a linear gradient to $100 \% \mathrm{MeOH}(0.1 \% \mathrm{TFA})$ over $40 \mathrm{~min}$, then isocratic conditions of $100 \% \mathrm{MeOH}(0.1 \% \mathrm{TFA})$ for an additional $10 \mathrm{~min}$, all at a flow rate of $9 \mathrm{~mL} / \mathrm{min}$. Sixty fractions $(60 \times 1 \mathrm{~min})$ were collected from the start of the HPLC run. Fractions containing UV-active material from each separate HPLC run were analyzed by ${ }^{1} \mathrm{H}$ NMR spectroscopy and LCMS, and high purity $(>95 \%)$ fractions were combined to give total yield.

\subsubsection{Compound 8}

5-Chloro-3-(4-chlorophenyl)-8-methyl-[1,2,4]triazolo[4,3- $\alpha]$ pyrazine (8). Pale pink amorphous solid (3.9 mg, 14\%); UV (MeOH) $\lambda_{\max }(\log \varepsilon) 224(4.44), 241(4.42), 308(3.83) \mathrm{nm} ;{ }^{1} \mathrm{H}$ NMR (500 MHz, DMSO- $\left.d_{6}\right) \delta_{\mathrm{H}} 2.86(3 \mathrm{H}, \mathrm{s}, \mathrm{H}-18), 7.63(2 \mathrm{H}, \mathrm{m}, \mathrm{H}-12, \mathrm{H}-14), 7.74(2 \mathrm{H}, \mathrm{m}$, H-11, H-15) 7.92 (1H, s, H-6); ${ }^{13} \mathrm{C}$ NMR (125 MHz, DMSO-d $\left.d_{6}\right) \delta_{\mathrm{C}} 20.2$ (C-18), 119.8 (C-5), 126.3 (C-10), 127.9 (C-12, C-14), 128.5 (C-6), 133.1 (C-11, C-15), 135.4 (C-13), 146.7 (C-9), 147.2 (C-3), 151.5 (C-8); (+)-LRESIMS $m / z$ (rel. int.) 279 (100) [M + H] $]^{+}$; (+)-HRESIMS $\mathrm{m} / z 279.0197[\mathrm{M}+\mathrm{H}]^{+}$(calcd for $\mathrm{C}_{12} \mathrm{H}_{9} \mathrm{Cl}_{2} \mathrm{~N}_{4}, 279.0199$ ), $301.0015[\mathrm{M}+\mathrm{Na}]^{+}$(calcd for $\mathrm{C}_{12} \mathrm{H}_{8} \mathrm{Cl}_{2} \mathrm{~N}_{4} \mathrm{Na}$, 301.0018).

\subsubsection{Compound $\mathbf{1 0}$}

4-(5-Chloro-8-methyl-1,2,4-triazolo[4,3- $\alpha$ ]pyrazin-3-yl)benzonitrile (10). Pale red amorphous solid (4.6 mg, 17\%); UV (MeOH) $\lambda_{\max }(\log \varepsilon) 225$ (4.32), 235 (4.29), 251 (4.19), $282(4.02) \mathrm{nm} ;{ }^{1} \mathrm{H}$ NMR (500 MHz, DMSO- $\left.d_{6}\right) \delta_{\mathrm{H}} 2.87$ (3H, s, H-19), 7.93 (2H, m, H-11, $\mathrm{H}-15), 7.96(1 \mathrm{H}, \mathrm{s}, \mathrm{H}-6), 8.04(2 \mathrm{H}, \mathrm{m}, \mathrm{H}-12, \mathrm{H}-14) ;{ }^{13} \mathrm{C}$ NMR $\left(125 \mathrm{MHz}, \mathrm{DMSO}-d_{6}\right) \delta_{\mathrm{C}}$ 20.2 (C-19), 113.0 (C-13), 118.4 (C-16), 119.8 (C-5), 128.7 (C-6), 146.76 ${ }^{\#}$ (C-3), 146.83" (C-9), 151.5 (C-8), 132.0 (C-10), 132.2 (C-11, C-15), 131.6 (C-12, C-14); (+)-LRESIMS m/z (rel. int.) $270(100)[\mathrm{M}+\mathrm{H}]^{+} ;(+)$-HRESIMS $\mathrm{m} / z 270.0540[\mathrm{M}+\mathrm{H}]^{+}\left(\right.$calcd for $\left.\mathrm{C}_{13} \mathrm{H}_{9} \mathrm{ClN}_{5}, 270.0541\right)$, $292.0358[\mathrm{M}+\mathrm{Na}]^{+}$(calcd for $\left.\mathrm{C}_{13} \mathrm{H}_{8} \mathrm{ClN}_{5} \mathrm{Na}, 292.0360\right)$. " Interchangeable signals

\subsubsection{Compound $\mathbf{1 1}$}

5-Chloro-3-[(4-difluoromethoxy)phenyl]-8-methyl-[1,2,4]triazolo[4,3- $\alpha$ ]pyrazine (11). Brown amorphous solid (12.3 mg, 40\%); UV (MeOH) $\lambda_{\max }(\log \varepsilon) 239$ (3.90), 309 (3.29) nm; ${ }^{1} \mathrm{H}$ NMR $\left(500 \mathrm{MHz}, \mathrm{DMSO}-d_{6}\right) \delta_{\mathrm{H}} 2.86(3 \mathrm{H}, \mathrm{s}, \mathrm{H}-21), 7.34(2 \mathrm{H}, \mathrm{m}, \mathrm{H}-12, \mathrm{H}-14), 7.40\left(1 \mathrm{H}, \mathrm{t},{ }^{2} J_{\mathrm{HF}}=73.7 \mathrm{~Hz}\right.$, $\mathrm{H}-17), 7.77(2 \mathrm{H}, \mathrm{m}, \mathrm{H}-11, \mathrm{H}-15), 7.91(1 \mathrm{H}, \mathrm{s}, \mathrm{H}-6) ;{ }^{13} \mathrm{C}$ NMR $\left(125 \mathrm{MHz}, \mathrm{DMSO}-d_{6}\right) \delta_{\mathrm{C}} 20.2$ (C-21), $116.2\left(\mathrm{t},{ }^{1} J_{\mathrm{CF}}=258.5 \mathrm{~Hz}, \mathrm{C}-17\right), 117.5(2 \mathrm{C}, \mathrm{C}-12, \mathrm{C}-14), 119.8(\mathrm{C}-5), 124.0$ (C-10), 128.5 (C-6), 133.3 (C-11, C-15), 146.7 (C-9), 147.4 (C-3), $151.5(\mathrm{C}-8), 152.5\left(\mathrm{t},{ }^{3} \mathrm{~J}_{\mathrm{CF}}=3.3 \mathrm{~Hz}\right.$, C-13); (+)-LRESIMS m/z (rel. int.) $311(100)\left[\mathrm{M}+\mathrm{H}^{+} ;(+)\right.$-HRESIMS $\mathrm{m} / z 311.0508[\mathrm{M}+\mathrm{H}]^{+}$ 
(calcd for $\mathrm{C}_{13} \mathrm{H}_{10} \mathrm{ClF}_{2} \mathrm{~N}_{4} \mathrm{O}, 311.0506$ ), $333.0327\left[\mathrm{M}+\mathrm{Na}^{+}\right.$(calcd for $\mathrm{C}_{13} \mathrm{H}_{9} \mathrm{ClF}_{2} \mathrm{~N}_{4} \mathrm{NaO}$, 333.0325).

\subsubsection{Compound $\mathbf{1 2}$}

3-[4-(Difluoromethoxy)phenyl]-8-methyl-5-(2,2,2-trifluoroethoxy)-[1,2,4]triazolo[4,3-a]pyrazine (12). White amorphous solid (8.5 mg, 22\%); UV (MeOH) $\lambda_{\max }(\log \varepsilon) 240$ (5.00), 309 (4.45) $\mathrm{nm} ;{ }^{1} \mathrm{H}$ NMR $\left(500 \mathrm{MHz}\right.$, DMSO- $\left.d_{6}\right) \delta_{\mathrm{H}} 2.78(3 \mathrm{H}, \mathrm{s}, \mathrm{H}-26), 4.96\left(2 \mathrm{H}, \mathrm{q},{ }^{2} J_{\mathrm{HF}}=8.5 \mathrm{~Hz}, \mathrm{H}-21\right)$, $7.28(2 \mathrm{H}, \mathrm{m}, \mathrm{H}-12, \mathrm{H}-14), 7.35\left(1 \mathrm{H}, \mathrm{t},{ }^{2} J_{\mathrm{HF}}=73.7 \mathrm{~Hz}, \mathrm{H}-17\right), 7.52(1 \mathrm{H}, \mathrm{s}, \mathrm{H}-6), 7.76(2 \mathrm{H}, \mathrm{m}$, H-11, H-15); ${ }^{13} \mathrm{C}$ NMR (125 MHz, DMSO- $\left.d_{6}\right) \delta_{\mathrm{C}} 19.8(\mathrm{C}-26), 66.0\left(\mathrm{q},{ }^{2} J_{\mathrm{CF}}=35.8 \mathrm{~Hz}, \mathrm{C}-21\right)$, $108.9(\mathrm{C}-6), 116.1\left(\mathrm{t},{ }^{1} J_{\mathrm{CF}}=258.5 \mathrm{~Hz}, \mathrm{C}-17\right), 117.7(\mathrm{C}-12, \mathrm{C}-14), 122.5\left(\mathrm{q},{ }^{1} J_{\mathrm{CF}}=277.3 \mathrm{~Hz}\right.$, C-22), 124.4 (C-10), 132.4 (C-11, C-15), 145.1 (C-8), 141.6 (C-5), 146.8 (C-3), 146.4 (C-9), $152.0\left(\mathrm{t},{ }^{3} J_{\mathrm{CF}}=3.2 \mathrm{~Hz}, \mathrm{C}-13\right)$; (+)-LRESIMS $\mathrm{m} / \mathrm{z}$ (rel. int.) $375(100)[\mathrm{M}+\mathrm{H}]^{+}$; (+)-HRESIMS $m / z 375.0874[\mathrm{M}+\mathrm{H}]^{+}$(calcd for $\left.\mathrm{C}_{15} \mathrm{H}_{12} \mathrm{~F}_{5} \mathrm{~N}_{4} \mathrm{O}_{2}, 375.0875\right)$, $397.0693[\mathrm{M}+\mathrm{Na}]^{+}$(calcd for $\left.\mathrm{C}_{15} \mathrm{H}_{11} \mathrm{~F}_{5} \mathrm{~N}_{4} \mathrm{NaO}_{2}, 397.0694\right)$.

\subsubsection{Compound 13}

3-[4-(Difluoromethoxy)phenyl]-8-methyl-5-(2-phenylethoxy)-[1,2,4]triazolo[4,3-a]pyrazine (13). White amorphous solid (17.1 mg, 43\%); UV (MeOH) $\lambda_{\max }(\log \varepsilon) 244$ (4.34), 312 (3.81) nm; ${ }^{1} \mathrm{H}$ NMR $\left(500 \mathrm{MHz}\right.$, DMSO- $\left.d_{6}\right) \delta_{\mathrm{H}} 2.72(3 \mathrm{H}, \mathrm{s}, \mathrm{H}-29), 2.86(2 \mathrm{H}, \mathrm{t}, J=6.5 \mathrm{~Hz}, \mathrm{H}-22), 4.42(2 \mathrm{H}$, $\mathrm{t}, J=6.5 \mathrm{~Hz}, \mathrm{H}-21), 6.91(2 \mathrm{H}, \mathrm{m}, \mathrm{H}-24, \mathrm{H}-28), 7.16(1 \mathrm{H}, \mathrm{m}, \mathrm{H}-26), 7.17(2 \mathrm{H}, \mathrm{m}, \mathrm{H}-25, \mathrm{H}-27)$, $7.29(2 \mathrm{H}, \mathrm{m}, \mathrm{H}-12, \mathrm{H}-14), 7.36\left(1 \mathrm{H}, \mathrm{t},{ }^{2} J_{\mathrm{HF}}=73.7 \mathrm{~Hz}, \mathrm{H}-17\right), 7.39(1 \mathrm{H}, \mathrm{s}, \mathrm{H}-6), 7.74(2 \mathrm{H}$, m, H-11, H-15); ${ }^{13}$ C NMR (125 MHz, DMSO- $\left.d_{6}\right) \delta_{\mathrm{C}} 19.7$ (C-29), 33.9 (C-22), 71.0 (C-21), $107.9(\mathrm{C}-6), 116.2\left(\mathrm{t},{ }^{1} J_{\mathrm{CF}}=258.2 \mathrm{~Hz}, \mathrm{C}-17\right), 117.6(2 \mathrm{C}, \mathrm{C}-12, \mathrm{C}-14), 124.8(\mathrm{C}-10), 126.4(\mathrm{C}-26)$, 128.2 (C-25, C-27), 128.7 (C-24, C-28), 132.6 (C-11, C-15), 137.4 (C-23), 142.8 (C-5), 143.2 (C8), $146.3(\mathrm{C}-3), 146.8(\mathrm{C}-9), 152.0\left(\mathrm{t},{ }^{3} J_{\mathrm{CF}}=3.2 \mathrm{~Hz}, \mathrm{C}-13\right) ;(+)$-LRESIMS $\mathrm{m} / z$ (rel. int.) 397 (100) $[\mathrm{M}+\mathrm{H}]^{+}$; (+)-HRESIMS $m / z 397.1470[\mathrm{M}+\mathrm{H}]^{+}$(calcd for $\mathrm{C}_{21} \mathrm{H}_{19} \mathrm{~F}_{2} \mathrm{~N}_{4} \mathrm{O}_{2}, 397.1471$ ), $419.1290[\mathrm{M}+\mathrm{Na}]^{+}$(calcd for $\mathrm{C}_{21} \mathrm{H}_{18} \mathrm{~F}_{2} \mathrm{~N}_{4} \mathrm{NaO}_{2}, 419.1290$ ).

3.4. General Procedure for the Late-Stage Functionalization Using Baran Diversinates ${ }^{\mathrm{TM}}$ on Heterocyclic Scaffolds

The scaffold $(0.1 \mathrm{mmol})$ was dissolved in DMSO $/ \mathrm{CH}_{2} \mathrm{Cl}_{2}(1: 1,250 \mu \mathrm{L}: 250 \mu \mathrm{L})$ before the addition of Diversinate ${ }^{\mathrm{TM}}(0.2 \mathrm{mmol}, 2$ eq.), TFA ( $40 \mu \mathrm{L}, 0.5 \mathrm{mmol}, 5$ eq.), and filtered $\mathrm{H}_{2} \mathrm{O}(100 \mu \mathrm{L})$. Reaction mixtures were stirred for $30 \mathrm{~min}$ at room temperature, cooled to $4{ }^{\circ} \mathrm{C}$. Then, $70 \%$ TBHP $(41 \mu \mathrm{L}, 0.3 \mathrm{mmol}, 3 \mathrm{eq}$.) was slowly added over $5 \mathrm{~min}$ and left to stir for $16 \mathrm{~h}$. All reactions were monitored by LCMS at $16 \mathrm{~h}$. If a minimal product had formed at $16 \mathrm{~h}$, an additional $0.2 \mathrm{mmol}$ of both Diversinate ${ }^{\mathrm{TM}}$ and $0.3 \mathrm{mmol}$ of TBHP was added and the reaction stirred for $24 \mathrm{~h}$ at room temperature prior to purification. Each crude reaction product was preadsorbed to $C_{18}$-bonded silica $(\sim 1 \mathrm{~g})$ and then packed into a guard cartridge that was subsequently attached to a semipreparative $\mathrm{C}_{18}$-bonded silica HPLC column. Isocratic conditions of $10 \% \mathrm{MeOH} / 90 \% \mathrm{H}_{2} \mathrm{O}(0.1 \%$ TFA) were held for the first $10 \mathrm{~min}$, followed by a linear gradient to $100 \% \mathrm{MeOH}(0.1 \%$ TFA) over $40 \mathrm{~min}$, then isocratic conditions of $100 \% \mathrm{MeOH}(0.1 \%$ TFA) for an additional $10 \mathrm{~min}$, all at a flow rate of $9 \mathrm{~mL} / \mathrm{min}$. Sixty fractions $(60 \times 1 \mathrm{~min})$ were collected from the start of the HPLC run. Fractions containing UV-active material were analyzed by ${ }^{1} \mathrm{H}$ NMR spectroscopy and LCMS, in order to identify products of interest.

\subsubsection{Compound 14}

5-Chloro-3-(4-chlorophenyl)-8-(trifluoromethyl)-[1,2,4]triazolo[4,3- $\alpha$ ]pyrazine (14). Yellow amorphous solid (6.4 mg, 19\%); UV (MeOH) $\lambda_{\max }(\log \varepsilon) 229$ (4.18), 245 (4.14), 330 (3.30) $\mathrm{nm} ;{ }^{1} \mathrm{H}$ NMR $\left(500 \mathrm{MHz}, \mathrm{DMSO}-d_{6}\right) \delta_{\mathrm{H}} 7.67(2 \mathrm{H}, \mathrm{m}, \mathrm{H}-12, \mathrm{H}-14), 7.75(2 \mathrm{H}, \mathrm{m}, \mathrm{Hz}, \mathrm{H}-11$, $\mathrm{H}-15), 8.03(1 \mathrm{H}, \mathrm{s}, \mathrm{H}-6) ;{ }^{13} \mathrm{C}$ NMR $\left(125 \mathrm{MHz}, \mathrm{DMSO}-d_{6}\right) \delta_{\mathrm{C}} 119.9\left(\mathrm{q},{ }^{1} J_{\mathrm{C}-\mathrm{F}}=275.1 \mathrm{~Hz}, \mathrm{C}-18\right)$, 125.6 (C-10), 143.4 (C-9), 127.8 (C-6), 128.0 (C-12, C-14), 133.2 (C-11, C-15), 135.8 (C-13), $137.4\left(\mathrm{q},{ }^{2} J_{\mathrm{CF}}=37.9 \mathrm{~Hz}, \mathrm{C}-8\right), 126.3(\mathrm{C}-5), 147.5$ (C-3); (+)-LRESIMS m/z (rel. int.) 333 
(100) $[\mathrm{M}+\mathrm{H}]^{+}$; (+)-HRESIMS $m / z 332.9915[\mathrm{M}+\mathrm{H}]^{+}$(calcd for $\mathrm{C}_{12} \mathrm{H}_{6} \mathrm{Cl}_{2} \mathrm{~F}_{3} \mathrm{~N}_{4}, 332.9916$ ), $354.9734[\mathrm{M}+\mathrm{Na}]^{+}$(calcd for $\left.\mathrm{C}_{12} \mathrm{H}_{5} \mathrm{Cl}_{2} \mathrm{~F}_{3} \mathrm{~N}_{4} \mathrm{Na}, 354.9736\right)$.

\subsubsection{Compound 15}

5-Chloro-3-(4-chlorophenyl)-8-(1,1-difluoroethyl)-[1,2,4]triazolo[4,3-a]pyrazine (15). Yellow amorphous solid ( $\left.t_{\mathrm{R}:} 37 \mathrm{~min}, 4.8 \mathrm{mg}, 15 \%\right)$; UV (MeOH) $\lambda_{\max }(\log \varepsilon) 227(5.00), 240$ (4.98), 311 (4.24) $\mathrm{nm} ;{ }^{1} \mathrm{H}$ NMR $\left(500 \mathrm{MHz}, \mathrm{DMSO}-d_{6}\right) \delta_{\mathrm{H}} 2.25\left(3 \mathrm{H}, \mathrm{t},{ }^{3} J_{\mathrm{HF}}=19.3 \mathrm{~Hz}, \mathrm{H}-20\right), 7.65(2 \mathrm{H}, \mathrm{m}, \mathrm{H}-12$, $\mathrm{H}-14), 7.75(2 \mathrm{H}, \mathrm{m}, \mathrm{H}-11, \mathrm{H}-15), 8.17(1 \mathrm{H}, \mathrm{s}, \mathrm{H}-6) ;{ }^{13} \mathrm{C}$ NMR $\left(125 \mathrm{MHz}, \mathrm{DMSO}-d_{6}\right) \delta_{\mathrm{C}} 22.8$ $\left(\mathrm{t},{ }^{2} J_{\mathrm{CF}}=25.5 \mathrm{~Hz}, \mathrm{C}-20\right), 119.1\left(\mathrm{t},{ }^{1} J_{\mathrm{CF}}=240.2 \mathrm{~Hz}, \mathrm{C}-19\right), 124.2(\mathrm{C}-5), 126.0(\mathrm{C}-10), 127.6(\mathrm{C}-6)$, 127.9 (C-12, C-14), 133.0 (C-11, C-15), 135.7 (C-13), 143.9 (C-9), 144.9 (t, ${ }^{2} J_{\mathrm{C}-\mathrm{F}}=31.3 \mathrm{~Hz}$, C-8), 147.1 (C-3); (+)-LRESIMS m/z (rel. int.) 329 (100) [M + H] $]^{+}$; (+)-HRESIMS m/z $329.0166[\mathrm{M}+\mathrm{H}]^{+}$(calcd for $\left.\mathrm{C}_{13} \mathrm{H}_{9} \mathrm{Cl}_{2} \mathrm{~F}_{2} \mathrm{~N}_{4}, 329.0167\right), 350.9985[\mathrm{M}+\mathrm{Na}]^{+}$(calcd for $\mathrm{C}_{13} \mathrm{H}_{8} \mathrm{Cl}_{2} \mathrm{~F}_{2} \mathrm{~N}_{4} \mathrm{Na}$, 350.9986).

\subsubsection{Compound $\mathbf{1 6}$}

3-(4-Chlorophenyl)-8-(1,1-difluoroethyl)-[1,2,4]triazolo[4,3-a]pyrazine (16). Yellow amorphous solid ( $\left.t_{\mathrm{R}:} 35 \mathrm{~min}, 5.0 \mathrm{mg}, 17 \%\right)$; UV (MeOH) $\lambda_{\max }(\log \varepsilon) 248$ (4.89), 279 (4.45) nm; ${ }^{1} \mathrm{H} \mathrm{NMR}\left(500 \mathrm{MHz}, \mathrm{DMSO}-d_{6}\right) \delta_{\mathrm{H}} 2.25\left(3 \mathrm{H}, \mathrm{t},{ }^{3} \mathrm{~J}_{\mathrm{HF}}=19.3 \mathrm{~Hz}, \mathrm{H}-18\right), 7.73(2 \mathrm{H}, \mathrm{m}, \mathrm{H}-12, \mathrm{H}-14)$, $7.98(2 \mathrm{H}, \mathrm{m}, \mathrm{H}-11, \mathrm{H}-15), 8.04(1 \mathrm{H}, \mathrm{d}, J=4.8 \mathrm{~Hz}, \mathrm{H}-6), 8.74(1 \mathrm{H}, \mathrm{d}, J=4.8 \mathrm{~Hz}, \mathrm{H}-5) ;{ }^{13} \mathrm{C} \mathrm{NMR}$ $\left(125 \mathrm{MHz}, \mathrm{DMSO}-d_{6}\right) \delta_{\mathrm{C}} 22.7\left(\mathrm{t},{ }^{2} J_{\mathrm{C}-\mathrm{F}}=25.6 \mathrm{~Hz}, \mathrm{C}-18\right), 119.5(\mathrm{C}-5), 120.0\left(\mathrm{t},{ }^{1} J_{\mathrm{C}-\mathrm{F}}=239.7 \mathrm{~Hz}\right.$, C-17), 124.4 (C-10), 128.5 (C-6), 129.5 (C-12, C-14), 130.3 (C-11, C-15), 135.6 (C-13), 142.6 (C-9), $146.4\left(\mathrm{t},{ }^{2} J_{\mathrm{C}-\mathrm{F}}=30.9 \mathrm{~Hz}, \mathrm{C}-8\right), 146.6(\mathrm{C}-3) ;(+)$-LRESIMS $\mathrm{m} / z$ (rel. int.) $295(100)[\mathrm{M}+\mathrm{H}]^{+} ;(+)$ HRESIMS $m / z 295.0557[\mathrm{M}+\mathrm{H}]^{+}$(calcd for $\left.\mathrm{C}_{13} \mathrm{H}_{10} \mathrm{ClF}_{2} \mathrm{~N}_{4}, 295.0557\right), 317.0378[\mathrm{M}+\mathrm{Na}]^{+}$ (calcd for $\mathrm{C}_{13} \mathrm{H}_{9} \mathrm{ClF}_{2} \mathrm{~N}_{4} \mathrm{Na}, 317.0376$ ).

\subsubsection{Compound $\mathbf{1 7}$}

5-Chloro-3-(4-chlorophenyl)-8-(4,4-difluorocyclohexyl)-[1,2,4]triazolo[4,3-a]pyrazine (17). Yellow amorphous solid ( $\left.t_{\mathrm{R}}: 35 \mathrm{~min}, 8.5 \mathrm{mg}, 22 \%\right)$; UV (MeOH) $\lambda_{\max }(\log \varepsilon) 227(4.78)$, 244 (4.79), 309 (4.12) nm; ${ }^{1} \mathrm{H}$ NMR (500 MHz, DMSO- $\left.d_{6}\right) \delta_{\mathrm{H}} 2.00$ and $2.14(4 \mathrm{H}, \mathrm{m}, \mathrm{H}-20$, $\mathrm{H}-24), 2.08$ and $2.17(4 \mathrm{H}, \mathrm{m}, \mathrm{H}-21, \mathrm{H}-23), 3.75(1 \mathrm{H}, \mathrm{m}, \mathrm{H}-19), 7.62(2 \mathrm{H}, \mathrm{m}, \mathrm{H}-12$, $\mathrm{H}-14), 7.74(2 \mathrm{H}, \mathrm{m}, \mathrm{H}-11, \mathrm{H}-15), 7.99(1 \mathrm{H}, \mathrm{s}, \mathrm{H}-6) ;{ }^{13} \mathrm{C}$ NMR $\left(125 \mathrm{MHz}, \mathrm{DMSO}-d_{6}\right) \delta_{\mathrm{C}}$ $26.7\left(\mathrm{~d},{ }^{3} J_{\mathrm{CF}}=9.6 \mathrm{~Hz}, \mathrm{C}-20, \mathrm{C}-24\right), 32.6\left(2 \mathrm{C}, \mathrm{dd},{ }^{2} J_{\mathrm{CF}}=23.8,23.8 \mathrm{~Hz} \mathrm{C}-21, \mathrm{C}-23\right), 38.5(\mathrm{C}-19)$, $120.1(\mathrm{C}-5), 123.9\left(\mathrm{dd},{ }^{1} \mathrm{~J}_{\mathrm{CF}}=239.3,241.6 \mathrm{~Hz}, \mathrm{C}-22\right), 126.3(\mathrm{C}-10), 127.8(\mathrm{C}-12, \mathrm{C}-14), 128.5$ (C6), 133.2 (C-11, C-15), 135.4 (C-13), 145.7 (C-9), 147.1 (C-3), 156.3 (C-8); (+)-LRESIMS m/z (rel. int.) $383(100)[\mathrm{M}+\mathrm{H}]^{+}$; (+)-HRESIMS $m / z 383.0636[\mathrm{M}+\mathrm{H}]^{+}$(calcd for $\mathrm{C}_{17} \mathrm{H}_{15} \mathrm{Cl}_{2} \mathrm{~F}_{2} \mathrm{~N}_{4}$, 383.0636), 405.0456 [M + Na] $]^{+}$(calcd for $\left.\mathrm{C}_{17} \mathrm{H}_{14} \mathrm{Cl}_{2} \mathrm{~F}_{2} \mathrm{~N}_{4} \mathrm{Na}, 405.0456\right)$.

\subsubsection{Compound 18}

3-(4-Chlorophenyl)-8-(4,4-difluorocyclohexyl)-[1,2,4]triazolo[4,3-a]pyrazine (18). Yellow crystals ( $\left.t_{\mathrm{R}:} 35 \mathrm{~min}, 7.7 \mathrm{mg}, 22 \%\right)$; mp 203-205 ${ }^{\circ} \mathrm{C}$; UV (MeOH) $\lambda_{\max }(\log \varepsilon) 247$ (4.91), 279 (4.57) $\mathrm{nm} ;{ }^{1} \mathrm{H}$ NMR (500 MHz, DMSO- $\left.d_{6}\right) \delta_{\mathrm{H}} 2.03$ and $2.15(4 \mathrm{H}, \mathrm{m}, \mathrm{H}-19, \mathrm{H}-23), 2.06$ and 2.17 (4H, m, H-20, H-22), 3.75 (1H, m, H-18), 7.71 (2H, m, H-12, H-14), 7.97 (2H, m, H-11, H-15), $7.90(1 \mathrm{H}, \mathrm{d}, J=4.9 \mathrm{~Hz}, \mathrm{H}-5), 8.49(1 \mathrm{H}, \mathrm{d}, J=4.9 \mathrm{~Hz}, \mathrm{H}-6) ;{ }^{13} \mathrm{C}$ NMR $\left(125 \mathrm{MHz}, \mathrm{DMSO}-d_{6}\right)$ $\delta_{\mathrm{C}} 26.7\left(\mathrm{~d},{ }^{3} J_{\mathrm{CF}}=9.6 \mathrm{~Hz}, \mathrm{C}-18, \mathrm{C}-22\right), 32.6\left(\mathrm{dd},{ }^{2} J_{\mathrm{C}-\mathrm{F}}=23.8,23.8 \mathrm{~Hz}, \mathrm{C}-19, \mathrm{C}-21\right), 38.9(\mathrm{C}-17)$, $115.6(\mathrm{C}-5), 123.9\left(\mathrm{dd},{ }^{1} J_{\mathrm{CF}}=239.5,241.6 \mathrm{~Hz}, \mathrm{C}-20\right), 124.7(\mathrm{C}-10), 129.4$ (C-12, C-14), 129.6 (C6), 130.0 (C-11, C-15), 135.3 (C-13), 144.7 (C-9), 146.4 (C-3), 157.6 (C-8); (+)-LRESIMS m/z (rel. int.) $349(100)[\mathrm{M}+\mathrm{H}]^{+}$; (+)-HRESIMS $m / z 349.1027[\mathrm{M}+\mathrm{H}]^{+}$(calcd for $\mathrm{C}_{17} \mathrm{H}_{16} \mathrm{ClF}_{2} \mathrm{~N}_{4}$, 349.1026), $371.0846[\mathrm{M}+\mathrm{Na}]^{+}$(calcd for $\mathrm{C}_{17} \mathrm{H}_{15} \mathrm{ClF}_{2} \mathrm{~N}_{4} \mathrm{Na}, 371.0846$ ).

\subsection{X-ray Crystallography Studies on Compounds 3, 5, 7, and 18}

Intensity data for compounds were collected with an Oxford Diffraction Synergy diffractometer using either $\mathrm{Cu}-\mathrm{K} \alpha$ radiation or Mo-K $\alpha$. The temperature during data collection was maintained at 100.0(1) K using an Oxford Cryosystems cooling device. The structure of each compound was solved by direct methods and difference Fourier 
Synthesis [25]. Hydrogen atoms bound to the carbon atom were placed at their idealized positions and included in subsequent refinement cycles. The hydrogen atoms attached to heteroatoms were located from different Fourier maps and refined freely with isotropic displacement parameters. Thermal ellipsoid plots were generated using the program Mercury [26] integrated within the WINGX suite of programs [27]. Crystallographic data for compounds 3, 5, 7, and 18 were deposited with the Cambridge Crystallographic Data Centre and assigned CCDC deposit codes 2068891-2068894, respectively.

\subsubsection{Crystal Data for Compound 3}

$\mathrm{C}_{14} \mathrm{H}_{9} \mathrm{~N}_{4} \mathrm{O}_{2} \mathrm{~F}_{5}, M=360.25, \mathrm{mp} 169-170{ }^{\circ} \mathrm{C}, \mathrm{T}=100.0(10) \mathrm{K}, \lambda=1.54184 \AA$, Orthorhombic, space group P bca $a=7.2017(1), b=14.1975(1), c=27.9870(3) \AA, V=2861.56(5) \AA^{3}, Z=8$, $D_{c}=1.672 \mathrm{Mg} \mathrm{M}^{-3} \mu(\mathrm{Cu}-\mathrm{K} \alpha)=1.413 \mathrm{~mm}^{-1}, F(000)=1456$, crystal size $0.298 \times 0.222 \times 0.084 \mathrm{~mm}^{3}$ $\theta_{\max }=77.25^{\circ}, 35469$ reflections measured, 3013 independent reflections $\left(\mathrm{R}_{\text {int }}=0.0446\right)$; the final $\mathrm{R}=0.0360\left[\mathrm{I}>2 \sigma(\mathrm{I}), 2809\right.$ data] and $w \mathrm{R}\left(\mathrm{F}^{2}\right)=0.0949$ (all data); $\mathrm{GOOF}=1.045$.

\subsubsection{Crystal Data for Compound 5}

$\mathrm{C}_{17} \mathrm{H}_{20} \mathrm{~F}_{2} \mathrm{~N}_{4} \mathrm{O}_{2} \mathrm{Si}, M=378.46, \mathrm{mp} 135^{\circ} \mathrm{C}, \mathrm{T}=100.0(10) \mathrm{K}, \lambda=0.71073 \AA$, Triclinic, space group $P-1 a=7.6807(2), b=15.5577(4), c=15.8460(5) \AA, \alpha=76.888(2)^{\circ} \beta=77.685(2)^{\circ}$ $\gamma=89.799(2)^{\circ} V=1799.70(9) \AA^{3}, Z=4, Z^{\prime}=2, D_{c}=1.397 \mathrm{Mg} \mathrm{M}^{-3} \mu(\mathrm{Mo}-\mathrm{K} \alpha)=0.170 \mathrm{~mm}^{-1}$, $F(000)=792$, crystal size $0.568 \times 0.305 \times 0.230 \mathrm{~mm}^{3} \theta_{\max }=37.28^{\circ}, 30807$ reflections measured, 13451 independent reflections; $\left(R_{\text {int }}=0.0548\right)$ the final $R=0.0685[I>\sigma 2(I)$, 9692 data] and $w \mathrm{R}\left(\mathrm{F}^{2}\right)=0.2131$ (all data); $\mathrm{GOOF}=1.049$.

\subsubsection{Crystal Data for Compound 7}

$\mathrm{C}_{11} \mathrm{H}_{6} \mathrm{~N}_{4} \mathrm{Cl}_{2}, M=265.10, \mathrm{mp} 175-176^{\circ} \mathrm{C}, \mathrm{T}=100.0(10) \mathrm{K}, \lambda=1.54184 \AA$, Orthorhombic, space group $P 2{ }_{1} 2_{1} 2_{1} a=3.8654(1), b=6.6836(2), c=41.0638(11) \AA, V=1060.87(5) \AA^{3}, Z=4$, $D_{c}=1.660 \mathrm{Mg} \mathrm{M}^{-3} \mu(\mathrm{Cu}-\mathrm{K} \alpha)=5.341 \mathrm{~mm}^{-1}, F(000)=1456$, crystal size $0.258 \times 0.066 \times 0.024 \mathrm{~mm}^{3}$ $\theta_{\max }=77.14^{\circ}, 3732$ reflections measured, 1975 independent reflections $\left(R_{\text {int }}=0.0464\right)$; the final $\mathrm{R}=0.0488[\mathrm{I}>2 \sigma(\mathrm{I}), 1835$ data $]$ and $w \mathrm{R}\left(\mathrm{F}^{2}\right)=0.1236$ (all data); $\mathrm{GOOF}=1.015$.

\subsubsection{Crystal Data for Compound 18}

$\mathrm{C}_{17} \mathrm{H}_{15} \mathrm{~F}_{2} \mathrm{~N}_{4} \mathrm{Cl}, M=348.78, \mathrm{mp} 203-205^{\circ} \mathrm{C}, \mathrm{T}=100.0(10) \mathrm{K}, \lambda=0.71073 \AA \AA$, Triclinic, space group $P-1 \quad a=8.9632(2), b=11.2309(4), c=16.0212(6) \AA, \alpha=103.560(3)^{\circ} \beta=94.906(2)^{\circ}$ $\gamma=97.188(3)^{\circ} V=1544.42(9) \AA^{3}, Z=4, Z^{\prime}=2, D_{c}=1.500 \mathrm{Mg} \mathrm{M}^{-3} \mu(\mathrm{Mo}-\mathrm{K} \alpha)=0.276 \mathrm{~mm}^{-1}$, $F(000)=720$, crystal size $0.570 \times 0.297 \times 0.031 \mathrm{~mm}^{3} \theta_{\max }=37.19^{\circ}, 33358$ reflections measured, 14415 independent reflections $\left(R_{\text {int }}=0.0453\right)$; the final $R=0.0473[\mathrm{I}>2 \sigma(\mathrm{I})$, 10306 data] and $w \mathrm{R}\left(\mathrm{F}^{2}\right)=0.1293$ (all data); $\mathrm{GOOF}=1.073$.

\subsection{In Vitro Anti-Plasmodial Image-Based Asexual Assay}

Plsamodium falciparum 3D7 and Dd2 parasites were cultured in RPMI1640 (Life Technologies, Camarillo, CA, USA) supplemented with $2.5 \mathrm{mg} / \mathrm{mL}$ Albumax II, 5\% AB human serum, $25 \mathrm{mM}$ HEPES, and $0.37 \mathrm{mM}$ hypoxanthine. Ring stage parasites were treated with compounds following two rounds of sorbitol synchronization, as previously described [23]. Artesunate and pyrimethamine were incorporated as controls. Following incubation of assay plates for $72 \mathrm{~h}$ at $37^{\circ} \mathrm{C}$, and $5 \% \mathrm{CO}_{2}$ and $5 \% \mathrm{O}_{2}$, parasites were stained with 2-(4-amidinophenyl)-1H-indole-6-carboxamidine (DAPI) and imaged using an Opera QEHS confocal imaging system (PerkinElmer, Waltham, MA, USA). Images were analyzed, as previously described, using Acapella spot detection software (PerkinElmer, Waltham, MA, USA) [23].

\subsection{In Vitro Cytotoxicity Assay}

Human embryonic kidney cells (HEK293) were maintained in DMEM (Life Technologies, Camarillo, CA, USA) containing 10\% FBS (Hyclone ${ }^{\mathrm{TM}}$ ThermoFisher, Melbourne, Australia). Cytotoxicity testing was undertaken, as previously described [24]. In brief, $5 \mu \mathrm{L}$ 
of test compound was added/well of black/clear tissue culture-treated, 384-well plates containing 3000 adherent HEK 293 cells/well in $45 \mu \mathrm{L}$ and incubated $72 \mathrm{~h}$ at $37^{\circ} \mathrm{C}$ in $5 \%$ $\mathrm{CO}_{2}$. After incubation, the supernatant was removed and replaced with $40 \mu \mathrm{L}$ of $10 \%$ Alamar Blue per well. Plates were incubated for 5-6 h and measured for fluorescence at 530-nm excitation and 595-nm emission. The \% inhibition was calculated using $0.4 \%$ DMSO (no inhibition) and $5 \mu \mathrm{M}$ puromycin (100\% inhibition) data. $\mathrm{IC}_{50}$ values were obtained by plotting \% inhibition against log dose using GraphPad Prism v.6 (San Diego, CA, USA) nonlinear regression with a variable slope plot.

\subsection{Biological Data Analysis}

Normalizing of raw data used the in-plate positive ( $5 \mu \mathrm{M}$ puromycin $100 \%$ inhibition) and negative (0.4\% DMSO-no inhibition) controls to obtain percent inhibition and then used to calculate $\mathrm{IC}_{50}$ values through a 4 parameter logistic curve fitting in GraphPad Prism v.6.

\section{Conclusions}

In summary, LSF using both photoredox and Diversinate ${ }^{\mathrm{TM}}$ chemistry on the OSM triazolopyrazine Series 4 scaffold resulted in the generation of 12 new analogues, which were fully characterized using spectrometric and spectroscopic data analysis. A number of minor and unexpected side products were generated during these studies, including two molecules resulting from a proposed disproportionation reaction. In vitro screening using both 3D7 and Dd2 strains of Plasmodium falciparum identified five compounds with moderate antimalarial activity $\left(\mathrm{IC}_{50}<9 \mu \mathrm{M}\right)$, all of which showed encouraging selectivity profiles as they displayed no toxicity against HEK293 cells at $80 \mu \mathrm{M}$. Collectively, these data indicate that this particular OSM series warrant further medicinal chemistry studies and that LSF is one strategy for generating new and lead-like antimalarial compounds.

Supplementary Materials: The following are available: 1D/2D NMR and HRMS spectra for compounds 2-6 and 8-18 and NMR data tables for 2-6 and 8-18.

Author Contributions: Conceptualization, M.J.C. and R.A.D.; methodology, D.J.G.J., M.J.C., and R.A.D.; validation, D.J.G.J., M.J.C., and R.A.D.; formal analysis, D.J.G.J., R.A.D., J.M.W., V.M.A., and K.Y.L.; investigation, D.J.G.J., R.A.D., J.M.W., V.M.A., and K.Y.L.; resources, R.A.D., M.J.C., V.M.A., C.H., and J.M.W.; data curation, D.J.G.J., R.A.D., J.M.W., V.M.A., and K.Y.L.; writing-original draft preparation, D.J.G.J., R.A.D., I.D.J., and V.M.A.; writing-review and editing, D.J.G.J., I.D.J., V.M.A., K.Y.L., M.J.C., C.H., J.M.W., and R.A.D.; visualization, D.J.G.J., R.A.D., J.M.W., and K.Y.L.; supervision, R.A.D. and M.J.C.; project administration, R.A.D.; funding acquisition, R.A.D., M.J.C., and V.M.A. All authors have read and agreed to the published version of the manuscript.

Funding: The authors acknowledge the National Health and Medical Research Council (Grant APP1024314 to R.A.D. and M.J.C.) and the Australian Research Council for support toward NMR and MS equipment (Grant LE140100119) and financial support (Grant LP120200339 to R.A.D.). V.M.A. acknowledges Medicines for Malaria Venture for continual financial support.

Institutional Review Board Statement: Consistent with the standards and principles of the Australian National Statement on Ethical Conduct in Human Research (2007), the Griffith University Human Research Ethics Committee determined that the project "In vitro high-throughput antimalarial drug screening, assay development and basic research on human malaria parasites" (Ref: 03/08/11019) does not require ethical approval. This decision was based on the proposed research only involving collection and analysis of de-identified blood samples provided by the Red Cross as per the material transfer agreement (19-05QLD-21).

Informed Consent Statement: Not required.

Data Availability Statement: The data presented in this study are contained within the article and Supplementary Material. 
Acknowledgments: D.J.G.J. would like to acknowledge Wendy Loa for NMR and MS training, and NatureBank's Russell Addison and Sasha Hayes for technical assistance. The authors would like to thank Alicja Andraszek and Emily Kennedy from the Discovery Biology team for assistance with the cell culture and technical assistance with the assays, respectively. The authors wish to thank and acknowledge the Australian Red Cross Blood Bank for the provision of fresh red blood cells in accordance with agreement 19-05QLD-21, without which antiplasmodial testing could not have been performed.

Conflicts of Interest: The authors declare no conflict of interest. The funders had no role in the design of the study; in the collection, analyses, or interpretation of data; in the writing of the manuscript; or in the decision to publish the results.

Sample Availability: Samples of the compounds are available from the authors.

\section{References}

1. Shapiro, G. 3,3-Difluoropiperidine Carbamate Heterocyclic Compounds as NR2B NMDA Receptor Antagonists. U.S. Patent 10294230B2, 1 June 2015.

2. Pasternak, A.; Pio, B.; Chobanian, R.; Harry; Shi, Z.-C.; Dong, S.; Guo, Y.; Walsh, P.; Shawn; Guo, Z. Inhibitors of the renal outer medullary potassium channel. J. Org. Chem. 2020, 85, 13438-13452. [CrossRef]

3. Lee, S.; Çil, O.; Diez-Cecilia, E.; Anderson, M.O.; Verkman, A.S. Nanomolar-potency 1,2,4-triazoloquinoxaline inhibitors of the kidney urea transporter UT-A1. J. Med. Chem. 2018, 61, 3209-3217. [CrossRef] [PubMed]

4. Ali, I.; Lee, J.; Go, A.; Choi, G.; Lee, K. Discovery of novel [1,2,4]triazolo[4,3-a]quinoxaline aminophenyl derivatives as BET inhibitors for cancer treatment. Bioorg. Med. Chem. Lett. 2017, 27, 4606-4613. [CrossRef] [PubMed]

5. Open Source Malaria Project wiki; Open Source Malaria project/Series 4. Available online: https://github.com/ OpenSourceMalaria/Series4/wiki (accessed on 20 January 2021).

6. Open Source Malaria Project Wiki; A new triazolopyrazine series for OSM series 4. Available online: http://malaria. ourexperiment.org/osdd_malaria_shared/7949/A_New_Triazolopyrazine_Series_for_OSM_Series_4.html (accessed on 20 January 2021).

7. Open Source Malaria Project wiki; Mechanism of Action: Possible PfATP4 Activity Deduced from Parasite Ion Regulation Asays. Available online: https:/ / github.com/OpenSourceMalaria/Series4/wiki/Mechanism-of-Action\%3A-Possible-PfATP4-ActivityDeduced-from-Parasite-Ion-Regulation-Assays (accessed on 22 January 2021).

8. Gilson, P.R.; Kumarasingha, R.; Thompson, J.; Zhang, X.; Penington, J.S.; Kalhor, R.; Bullen, H.E.; Lehane, A.M.; Dans, M.G.; De Koning-Ward, T.F.; et al. A 4-cyano-3-methylisoquinoline inhibitor of Plasmodium falciparum growth targets the sodium efflux pump PfATP4. Sci. Rep. 2019, 9, 1-15. [CrossRef] [PubMed]

9. Vaidya, A.B.; Morrisey, J.M.; Zhang, Z.; Das, S.; Daly, T.M.; Otto, T.D.; Spillman, N.J.; Wyvratt, M.; Siegl, P.; Marfurt, J.; et al. Pyrazoleamide compounds are potent antimalarials that target $\mathrm{Na}+$ homeostasis in intraerythrocytic Plasmodium falciparum. Nat. Commun. 2014, 5, 5521. [CrossRef] [PubMed]

10. Spillman, N.J.; Kirk, K. The malaria parasite cation ATPase PfATP4 and its role in the mechanism of action of a new arsenal of antimalarial drugs. Int. J. Parasitol. Drugs Drug Resist. 2015, 5, 149-162. [CrossRef] [PubMed]

11. Rosling, J.E.O.; Ridgway, M.C.; Summers, R.L.; Kirk, K.; Lehane, A.M. Biochemical characterization and chemical inhibition of PfATP4-associated Na+-ATPase activity in Plasmodium falciparum membranes. J. Biol. Chem. 2018, 293, 13327-13337. [CrossRef] [PubMed]

12. Open Source Malaria Project Wiki; Synthesis of the Ether Linked Series. Available online: https://github.com/OpenSourceMalaria/ Series4/wiki/Synthesis-of-the-Ether-Linked-Series (accessed on 23 January 2021).

13. Tse, E. Open Source Malaria: Potent Triazolopyrazine-Based Antiplasmodium Agents That Probe an Important Mechanism of Action. Ph.D. Thesis, University of Sydney, Sydney, Australia, January 2019.

14. Open Source Malaria Project wiki; Compounds sent for testing in Dundee, December 2017 \#10. Available online: https: / / github.com/OpenSourceMalaria/Series4/issues/10 (accessed on 20 January 2021).

15. Open Source Malaria Project wiki; OpenSourceMalaria/Series4/Sources of Data. Available online: https://github.com/ OpenSourceMalaria/Series4/wiki/Sources-of-Data (accessed on 20 February 2021).

16. Eryilmaz, E. Multi-targeted anti-leukemic drug design with the incorporation of silicon into Nelarabine: How silicon increases bioactivity. Eur. J. Pharm. Sci. 2019, 134, 266-273. [CrossRef] [PubMed]

17. Korsik, M.; Tse, E.G.; Smith, D.G.; Lewis, W.; Rutledge, P.J.; Todd, M.H. tele-Substitution reactions in the synthesis of a prom-ising class of 1,2,4-triazolo[4,3-a]pyrazine-based antimalarials. J. Org. Chem. 2020, 85, 13438-13452. [CrossRef] [PubMed]

18. DiRocco, D.A.; Dykstra, K.; Krska, S.; Vachal, P.; Conway, D.V.; Tudge, M. Late-stage functionalization of biologically active heterocycles through photoredox catalysis. Angew. Chem. Int. Ed. 2014, 53, 4802-4806. [CrossRef] [PubMed]

19. Verschueren, R.H.; De Borggraeve, W.M. Electrochemistry and photoredox catalysis: A comparative evaluation in organic synthesis. Molecules 2019, 24, 2122. [CrossRef] [PubMed]

20. Kuttruff, C.A.; Haile, M.; Kraml, J.; Tautermann, C.S. Late-stage functionalization of drug-like molecules using Diversinates. ChemMedChem 2018, 13, 983-987. [CrossRef] [PubMed] 
21. Sander, T.; Freyss, J.; Von Korff, M.; Rufener, C. DataWarrior: An open-source program for chemistry aware data visualization and analysis. J. Chem. Inf. Model. 2015, 55, 460-473. [CrossRef]

22. Lipinski, C.A.; Lombardo, F.; Dominy, B.W.; Feeney, P.J. Experimental and computational approaches to estimate solubility and permeability in drug discovery and development settings. Adv. Drug Deliv. Rev. 2001, 46, 3-26. [CrossRef]

23. Duffy, S.; Avery, V.M. Development and optimization of a novel 384-well anti-malarial imaging assay validated for highthroughput screening. Am. J. Trop. Med. Hyg. 2012, 86, 84-92. [CrossRef] [PubMed]

24. Fletcher, S.; Avery, V.M. A novel approach for the discovery of chemically diverse anti-malarial compounds targeting the Plasmodium falciparum coenzyme A synthesis pathway. Malar. J. 2014, 13, 343. [CrossRef] [PubMed]

25. Sheldrick, G.M. Crystal structure refinement with SHELXL. ACTA Crystallogr. Sect. C 2015, 71, 3-8. [CrossRef]

26. Macrae, C.F.; Bruno, I.J.; Chisholm, J.A.; Edgington, P.R.; McCabe, P.; Pidcock, E.; Rodriguez-Monge, L.; Taylor, R.J.; Van De Streek, J.; Wood, P.A. Mercury CSD 2.0- new features for the visualization and investigation of crystal structures. J. Appl. Crystallogr. 2008, 41, 466-470. [CrossRef]

27. Farrugia, L.J. WinGX suite for small-molecule single-crystal crystallography. J. Appl. Crystallogr. 1999, 32, 837-838. [CrossRef] 